"This is the peer reviewed version of the following article: [Financial Management, 2020] which has been published in final form at [https://onlinelibrary.wiley.com/doi/10.1111/fima.12291] purposes in accordance with Wiley Terms and Conditions for Self-Archiving." 


\title{
Corporate Watchdogs
}

\author{
Marco Navone* ${ }^{*} \dagger$ \\ University of Technology Sydney \\ marco.navone@uts.edu.au
}

Thomas To
University of Sydney
thomas.to@sydney.edu.au

This Version: July 2019

*Corresponding author. Tel.: +61-2-95147736.

$\dagger$ We thank Ronald Masulis, Susan Thorp, TingTing Liu and participants to the Annual FMA conference for helpful comments and discussions. We are also grateful to François Derrien and Jarrad Harford for sharing with us their data with us. 


\title{
Corporate Watchdogs
}

\begin{abstract}
We investigate the role of financial analysts as corporate watchdogs. We show that firms that are subject to intense analyst monitoring are more likely to be investigated by the SEC or to be the subject of a securities class action. Using cross-sectional variations in managerial entrenchment we find that this effect is not a reflection of the "dark side of analyst coverage", analysts pushing executives to misbehave to exceed short-term expectations. Our findings are robust to different identification strategies addressing the endogeneity of analyst coverage decisions.
\end{abstract}

JEL classification: G14, G24, G34.

Keywords: Financial Analysts, Litigation Risk, Managerial Misbehavior. 


\section{Introduction}

Financial analysts are in the business of producing valuable firm-specific information that they then sell to interested investors (either directly or bundled with brokerage services). In the last ten years a growing body of literature has analyzed how this activity affects managerial behavior.

Some authors have showed that the increased information availability improves firms' access to financial markets which allows firms to invest more (Kelly and Ljungqvist, 2012; Derrien and Kecskés, 2013), while others have pointed out that it may also force company executives to focus on meeting short term earnings expectations and forgo valuable long term investment projects (Graham, Harvey, and Rajgopal, 2005; He and Tian, 2013; Irani and Oesch, 2016).

Accounting information produced by the company is often the base for an analyst's internal evaluation of firm prospects. In the process of producing earnings expectations and target prices analysts implicitly (and sometimes explicitly) judge the quality of the company financial statements. They may, for example, point out that current earnings appear inflated through accounting practices that, although maybe legal, do not reflect the company's true profitability. Numerous studies (Yu, 2008; Irani and Oesch, 2013; Chen, Harford, and Lin, 2015) show that the number of analysts covering a firm is inversely correlated with the size of abnormal accruals, widely used in the accounting literature as a proxy for "creative" accounting.

In this paper we investigate the channel through which financial analysts are able to affect the quality of financial statements. Specifically, we investigate whether analyst coverage affects the probability of corporate litigation. The basic idea is that an un-ethical corporate executive would decide to misbehave (manipulate earnings) if the expected benefit exceeds the expected cost. This last quantity can be seen as the product of the probability of being caught times the damage in case the misbehavior is discovered (criminal charges, reputational loss, legal fees, fines, etc.). Here we posit that financial analysts, as information providers, increase the probability that managerial misbehavior will be ultimately discovered. As a result of this increased litigation risk, other factors being equal, corporate executives will choose to produce higher quality accounting 
information.

We fully acknowledge that financial analysts are not the only actors constraining managerial behavior through information production and dissemination. Various contributions in the literature have analyzed the competing roles of different information providers. Piotroski and Roulstone(2004), for example, explicitly model the competing information production role of financial analysts, institutional investors and corporate insiders (through the mandatory disclosure of their trading activity). In this paper we focus on the role of financial analysts while controlling for the level of institutional ownership in any given company. All our results should thus be interpreted as the "additional effect" of analyst coverage. We also show that information production by financial analysts is a substitute for the action of institutional investors by showing that the effect of analyst coverage is weaker in companies with large institutional ownership.

In our empirical analysis we consider two different types of litigation events: Accounting and Auditing Enforcement Releases (AAERs) issued by the SEC during or at the conclusion of an investigation against a company or an officer for alleged accounting misconduct, and securities class actions filed by investors who suffered economic injury as a result of violations of the securities laws. We show that after controlling for firm characteristics that affect the demand for brokerage (and analysts) services as well as for observable measures of managerial misbehavior, an increase of coverage of one standard deviation increases the probability of being involved in a litigation event by $30 \%-53 \% .^{1}$

We fully acknowledge that a second, and more sinister, explanation can be given for our empirical evidence. Authors have recently pointed to a possible "dark side" of analyst coverage: by increasing the visibility of firm (short-term) performance analysts may create excessive pressure for the company executives to meet short term earnings goals. For example company executives may underinvest in R\&D (He and Tian, 2013) or manipulate earnings through, for example, artificially anticipating the timing of sales (Irani and Oesch, 2016). Here we acknowledge the possibility

\footnotetext{
${ }^{1}$ From $1.1 \%$ to $1.43 \%$ for Accounting and Auditing Enforcement Releases and from $1.82 \%$ to $2.79 \%$ for securities class actions.
} 
that the increase of litigation risk associated with an increase in coverage, may not be a function of better monitoring but of an increase pressure on the executives to misbehave.

In order to distinguish between these two alternative hypothesis (discipline vs pressure) we use time-series and cross-sectional variations in managerial entrenchment. A highly entrenched manager will not feel an excessive pressure to meet short term goals because he/she cannot be punished for underperforming. Therefore our pressure hypothesis predicts that when managerial entrenchment is high, higher coverage should not lead to more misbehavior (and thus litigation risk). Conversely in firms with highly entrenched managers is exactly when the external discipline role of analysts becomes very valuable because mechanisms of internal governance often fails to properly control entrenched managers (Hermalin and Weisbach, 1998; Ryan and Wiggins, 2004; Arena and Ferris, 2007) and (small) shareholders in these firms would rely on external sources of information in order to protect themselves either by "voting with their feet" or through legal means. Our discipline hypothesis thus makes an opposing prediction that in firms with entrenched managers the relationship between coverage and litigation risk should be particularly strong.

By using different proxies of managerial entrenchment based on the Governance Index of Gompers, Ishii, and Metrick (2003) and on the presence of large institutional investors we show a uniform support for the discipline hypothesis. Hence, at least in this case, we find no trace of the "dark side" to analyst coverage. That is, the increase in litigation risk associated with an increase in the number of analysts following a firm reflects the disciplining role of analysts. This in turn offers a clearer picture of the channel through which financial analysts are able to affect the behavior of company executives, at least in terms of the quality of the financial/accounting information provided to the public.

Research on financial analysts has long been aware of the endogeneity of analysts' coverage decisions. Unobserved factors that drive an analyst's decision to cover a specific firm may also drive the SEC to investigate the same firm (or a tort lawyer to initiate a class action). We address this endogeneity issue with a quasi-natural experiment analyzing the change in litigation risk around the exogenous drop in coverage due to the merger of two brokerage houses (as in Hong and Kacperczyk, 
2010) or the closure of a brokerage establishment (as in Kelly and Ljungqvist, 2012). Our main result is robust to this specification, both in significance and in magnitude.

Our results contribute first and foremost to the literature on the role analysts in corporate governance. Prior studies find that firms covered by more analysts engage in less earnings management (Yu, 2008; Irani and Oesch, 2013; Chen, Harford, and Lin, 2015), and the authors attribute their results to the monitoring role of analysts first proposed by Jensen and Meckling (1976). In this paper, we present evidence that it is the monitoring role of analysts, the ability of analysts to discover and reveal managerial misbehavior, which forces corporate executives to produce higher quality accounting information. Our paper is closest in spirit to Dyck, Morse, and Zingales (2010) as they find that analysts revealed 14\% of the 216 class action lawsuits from 1996 to 2004. While this paper presents very compelling evidence about the role of financial analysts in discovering corporate frauds, its scope is, in a sense, quite limited. Financial analysts are effective corporate watchdogs not only when they unearth unhealthy managerial practices, but also when they enable other actors to do the same. By providing an external assessment of corporate accounts they may enable other actors to discover weaknesses or inconsistencies. The analyst may not be the one to blow the whistle but may have still played a key role in the process. Here we extend the analysis of Dyck, Morse, and Zingales (2010) by examining how the information production role of analysts can enable both themselves and other parties to better detect managerial misbehavior. More importantly, our empirical design allows us to identify whether the frauds revealed are caused by the bright side (discipline) or the dark side (pressure) of analyst activity.

Our study is also related to the literature on the relationship between internal and external governance mechanisms. Existing evidence is unclear as to whether internal governance mechanisms (provided by the board and institutional investors) and external governance mechanisms (provided by the managerial labor market and the market for corporate control) act as complements or substitutes (Agrawal and Knoeber, 1996; Shleifer and Vishny, 1997; Cremers and Nair, 2005; Gillan, Hartzell, and Starks, 2011). We contribute to this literature by showing 
that the external discipline role of analysts is extremely valuable in firms with entrenched managers as it is very difficult for internal governance mechanisms to restrain their behavior in these firms.

The rest of the paper is organized as follows: Section 2 develops the hypotheses. Section 3 introduces our dataset. Section 4 analyzes the link between coverage and litigation risk. Section 6 address the issue of endogeneity of analyst coverage decisions. Section 7 distinguishes between disciplining and pressure hypotheses. Section 8 concludes.

\section{Hypothesis development}

\subsection{Financial analysts and managerial discipline}

As accounting and finance professionals, financial analysts interact directly with the top management on a consistent basis before disseminating information to the general public. Jensen and Meckling (1976) posit that the unique information intermediary role of analysts should help them to monitor corporate executives and reduce the agency costs associated with the separation of ownership and control. Empirical findings in the past decade validate this proposition. $\mathrm{Yu}(2008)$ finds that firms covered by less analysts engage in more earnings management, while Irani and Oesch (2013) and Chen, Harford, and Lin (2015) using an experimental design, find that after a firm experiences an exogenous decrease in analyst coverage its managers are more likely to engage in earnings management activities.

Analysts are in a unique position to detect managerial misbehavior due to their analytical skills and their access to the top management. Moreover they also possess the right incentives as they are ethically restricted from having any financial interest in the firms they cover and they can benefit from the notoriety resulting from uncovering some high profile scandal. As a result of this unique combination of skills, access and incentives the presence of financial analysts would increase the probability that misbehavior will be detected. This view is consistent with Kedia and Philippon (2009) who predict that managers would have a greater incentive to rent-seek when facing a lower 
probability of detection by external monitors.

One could argue that, in equilibrium, this increased monitoring should lead to lower levels of misbehavior and hence lower litigation risk. However, in our models we control for visible signs of managerial misbehavior and hence estimates, to the extent we can, a conditional probability of litigation. While it may be true that increased monitoring reduces instances of managerial misbehavior (Yu, 2008; Kedia and Philippon, 2009), executives who still decide to pursue legally questionable endeavors are more likely to be fired. On the surface, empirical evidence by Dyck, Morse, and Zingales (2010) showing that analysts revealed 14\% of the class action lawsuits from 1996 to 2004 seems to suggest analysts help to discipline managers.

\subsection{Financial analysts and managerial pressure}

Prior literature suggests that there is also a "dark side" to financial analysts: the excessive pressure they impose on corporate managers to meet short term earnings expectations. Studies have shown that beating forecasts increases short-term returns (Bartov, Givoly, and Hayn, 2002; Bhojraj, Hribar, Picconi, and McInnis, 2009) while missing forecasts can lead to a reduction in bonuses for the CEO (Matsunaga and Park, 2001) and a decrease in stock prices for the firm (Skinner and Sloan, 2002). As a result, a majority of executives would invest less in innovation and advertising expense in order to meet the short term earnings benchmarks (Graham, Harvey, and Rajgopal, 2005; He and Tian, 2013). A recent study by Irani and Oesch (2016) shows that managers in firms covered by more analysts also try to conceal true firm performance by engaging in real earnings management performed predominantly via the offering of price discounts to temporarily increase sales, overproduction to report lower cost of goods sold, and reduction of discretionary expenditures to improve reported margins. Overall, the findings of these studies collectively suggest that analyst coverage also provides a strong incentive for corporate managers to misbehave in order to meet short term earnings expectations. The dark side of analyst coverage could also explain our main empirical finding: firms covered by more analysts are more likely to be involved in litigation not because of the more intense monitoring, but because the additional 
pressure to meet short-term expectations provides additional incentives for top management to misbehave.

Since both the discipline and the pressure hypotheses imply a positive effect of analyst coverage on litigation risk, we cannot easily distinguish between the two. In order to identify the mechanism behind this empirical evidence, we use time-series and cross-sectional variations in managerial entrenchment. A critical feature of this identification strategy is that the discipline and pressure hypotheses lead to two opposite empirical predictions when we condition on the entrenchment level of the management. The idea is that under the pressure hypothesis we should observe a weaker effect of coverage on litigation risk for highly entrenched managers as these managers would feel less pressure to meet or beat analyst expectations because they cannot be easily punished in case of underperformance. Conversely in firms with highly entrenched managers is exactly when the discipline role of analysts becomes very valuable because mechanisms of internal governance often fails to control powerful managers (Hermalin and Weisbach, 1998; Ryan and Wiggins, 2004) and in these firms the (small) shareholders will more heavily rely on external sources information to protect their investment. Our discipline hypothesis thus makes an opposite prediction in that for firms with entrenched managers the relationship between coverage and litigation risk should be particularly strong.

\section{Data}

We use data from the COMPUSTAT-CRSP merged database on public companies listed in the three major US stock markets from 1988 to 2016 . We restrict our sample to firm-year observations where the initial value of total assets is not smaller than $\$ 100$ million and the initial stock price is above (or equal to) $\$ 1$. To account for the effect of institutional investors, which is positively correlated with analyst coverage (O’Brien and Bhushan, 1990) and could also affect litigation risk due to their monitoring role, we extract institutional ownership information from Thomson Reuters 13(f) filings and control for institutional ownership in all of the tests. After matching the 
firms with the Institutional Brokers Estimate System $(\mathrm{I} / \mathrm{B} / \mathrm{E} / \mathrm{S})$ database which provides data on financial analysts and dropping observations with missing values for the accounting variables of interest, we obtain a sample of 60,577 firm/year observations with 7,055 unique firms. In the second part of the paper we also consider governance data. As a proxy for governance quality we use the G-Index from Gompers, Ishii, and Metrick (2003) provided by Institutional Shareholder Services (formerly RiskMetrics).

\subsection{Securities class action lawsuits}

We obtain data on filings of securities class action lawsuits from the Stanford Law School Securities Class Action Clearinghouse. ${ }^{2}$ These data begin in 1996 and continue through current time. Common classes of examples include omitting material information; artificially inflated earnings, revenue, sales and assets; and premature revenue recognition. After applying our sample selection criteria, we carefully match the lawsuit firms by ticker symbol, company name and date with the Compustat and $\mathrm{I} / \mathrm{B} / \mathrm{E} / \mathrm{S}$ database. This matching process leaves us with a final sample consisting of 994 lawsuit events from 809 unique firms.

Using securities class action lawsuits to identify fraud offers certain advantages over other approaches. As Karpoff, Lee, and Martin (2008) mention, identifying fraud using press releases or private lawsuits can miss many instances of fraud and that many targeted companies get delisted before regulators formally file charges. Class action lawsuits, on the other hand, tend to be filed quickly after the disclosure of violations, on average one day after the trigger event announcement. However, a potential drawback of using class action lawsuits to identify fraud is that the investigation phase in lawsuits follows the filing of the lawsuit, whereas for federal enforcement actions such as AAERs, the investigation phase precedes enforcement. Therefore, our lawsuit sample may include firms with alleged fraud that may eventually be dismissed. In order to solve this problem, we also use AAERs as a proxy for fraud.

\footnotetext{
${ }^{2}$ http://securities.stanford.edu.
} 


\subsection{Accounting and Auditing Enforcement Releases}

Since 1982, the Securities and Exchange Commission (SEC) has issued AAERsduring or at the conclusion of an investigation against a company, an auditor, or an officer for alleged accounting and/or auditing misconduct. Most AAERs relate to revenue recognition, misstatement of expense/shareholder equity account, capitalization of costs as assets, and misstatement of accounts receivable. We obtain the dataset from Hass School of Business, University of California Berkeley. After matching firms with AAERs by Central Index Key (CIK) and date with the Compustat and IBES database, our final sample includes 588 AAER filings from 375 different firms. As mentioned before, the investigation phase precedes the issuance of AAERs. The SEC has a limited budget, so it only selects firms where there is strong evidence of manipulation. For example, some of the firms are those that restate earnings or have large write-offs such as Enron or Xerox, or other firms that havealready been identified by the press as having misstated earnings (see Miller, 2006). Therefore, the advantage of the AAER sample is that we can be certain the SEC has identified manipulating firms (the Type I error rate is low).

In our analysis we consider securities class action lawsuit and AAERs separately. As a robustness we also construct a synthetic Litigation Event variable that combines the two events. This yields a sample of 1,545 incidents from 613 distinct firms. The number of fraud firms varies by year and industry. For example, there were 125 fraud firms in 2002, but only 48 in 1997. In terms of industry, most fraud firms are in the technology $(27.70 \%)$, followed by healthcare $(13.92 \%)$. The rate of litigation also varies through time for a given sector. For example, the share of litigation attributable to firms in the technology sector was high between 1999 and 2000 (32.44\%) during the Dot-com bubble, while financial firms had a large share of litigation in 2008 (34.78\%) during the financial crisis.

Most of this industry/time variation can be explained by changes in market valuations. Accounting manipulation and other forms of improper behavior are usually aimed at propping up the market value of a stock and this leads to the evidence in Table II where we see that firms 
involved in fraud events have higher Tobin's Q than the general sample (especially when paired with lower return on assets). We also see that firms involved in litigation events tend to be larger. This makes sense as the size of a firm serves as a proxy for the possible gains from a security class action, and with respect to AAERs the SEC is also more likely to direct its limited resources in investigating larger firms. As expected we also see that litigation firms have a lower ratio of fixed to total assets (indicating a greater facility for creative accounting) and a higher level of abnormal accruals.

Finally we see that firms involved in litigation events are, on average, covered by more than 12 analysts versus an average coverage of 8.5 for the firms that have not been involved in litigation events. While this univariate evidence is per se suggestive, we need to be careful in the interpretation as we know from prior literature (see for example Bhushan, 1989 and McNichols and O'Brien, 1997) that analysts have incentives to cover larger firms and firms with a strong economic performance. Further analysis will be needed to properly assess the causal relationship.

\section{[Place Table I about here]}

\section{[Place Table II about here]}

\section{Litigation Risk and coverage}

Numerous studies (Yu, 2008; Irani and Oesch, 2013; Chen, Harford, and Lin, 2015) show that the number of analysts covering a firm has a positive effect on accounting quality (as measured by earnings manipulation via abnormal accruals). Here we argue that this effect is channeled via an increase in the probability of being caught as analysts are likely to shed light on inconsistencies and unusual or suspect accounting practices when they perform in-depth analysis of firms' accounting information. Moreover the information that they provide to the public may also enable other actors to unveil fraudulent behavior. 
As a first step in the analysis of this hypothesis we estimate a probit model where the probability of being involved in a litigation event is a function of analyst coverage and a series of firm-specific control variables.

$$
\operatorname{Pr}\left(F_{i t}=1\right)=\Phi\left(\alpha+\beta \text { Coverage }_{i t}+\gamma \text { Controls }_{i t}+\text { Year }_{t}+\text { Industry }_{k}\right)
$$

$F_{i t}$ is a dummy variable equal to 1 if firm $i$ has been involved in a litigation event during year $t$ and $\Phi$ is the Cumulative Distribution Function of the standard normal distribution.

The main variable of interest is the (natural logarithmofthe) number of analysts covering the firm at the beginning of the period (Coverage ${ }_{i t}$ ). The logarithmic transformation is standard in the analysts literature and reflects the assumption that the quantity of original information available does not grow linearly with the number of analysts covering a firm.

Controls $_{i t}$ is a vector of firm-specific characteristics that are likely to affect the demand for analysts services and may also have an unspecified effect on the outcome variable. The specific consideration of these quantities allows us to conduct a cleaner estimation of the residual effect of analyst coverage on the litigation risk.

In this model, we consider the size of the firm (natural logarithm of total assets), growth opportunities (Tobin's Q), profitability (ROA), leverage, percentage of fixed assets, cash flow volatility, reliance on external financing and institutional ownership. The formulation of each variable is detailed in Table I.

Litigation risk is also clearly a function of managerial behavior. Firms that implement shoddy accounting practices or engage in blatant earnings manipulation are more likely to be audited or sued regardless of the action of financial analysts. Therefore in an alternative specification of our model we also control for a number of proxies for accounting and real earnings manipulation derived from publicly available information.

As a proxy for accounting quality we first consider the same measure of abnormal accruals implemented by Yu(2008) based on a modified version of the Jones model (Jones, 1991; Dechow, 
Sloan, and Sweeney, 1995), which estimates discretionary accruals from cross-sectional regressions of total accruals on changes in sales and on property, plant, and equipment (PPE) within industries (The details of the calculations are described in Appendix).

In addition to accounting earnings management, Irani and Oesch (2016) show that a closer scrutiny by financial analysts may induce managers to substitute accounting earnings management with real earnings manipulation. While our first type of litigation (AAERs) is focused on accounting irregularities, shareholders litigation may also be triggered by a wider range of managerial misbehavior and thus is important to also control for these factors.

Irani and Oesch (2016) consider three forms of real activity manipulation:

- Sales manipulation achieved by acceleration of the timing of sales via more favorable credit terms or steeper price discounts.

- Reduction of discretionary expenditures, which include SG\&A expenses, advertising, and R\&D.

- Reporting a lower cost of goods sold (COGS) by increasing production.

We follow their work and consider abnormal levels of cash flow from operations, discretionary expenses, and production costs as additional variables in the alternative specification of our model (the details of the calculations are provided in Appendix). Finally, our models also include year and industry fixed effects (built on SIC 2-digit codes), and all standard errors are clustered at the firm level.

We start with a parsimonious model that regresses AAERs on our key variable of interest, Coverage $_{i t}$ and a set of control variables that proxies for the demand of brokerage services. Results in model (1) of Table III show that there is a positive and significant relationship between analyst coverage and the probability of receiving AAERs. In column (2), we add another set of control variables that proxies for managerial misbehavior. The coefficient estimate of analyst coverage continues to be positive and statistically significant at the $1 \%$ level with no significant change in magnitude. Similarly, we analyze the relationship between the probability of being involved in securities class actions and analyst coverage in columns (3) and (4), and we obtain similar results. 
To sum up, we combine the two types of litigation events and regress it on analyst coverage in columns (5) and (6). The coefficient estimate of analyst coverage continues to be positive and statistically significant at the $1 \%$ level.

It is important to remember that analysts are not the only actors capable of developing and disseminating firm-specific information. Following the intuition of Piotroski and Roulstone (2004), we specifically include in the model the level of institutional ownership to account for the information discovery role of institutional investors. The estimated coefficient for our coverage variable captures the additional informational effect of financial analysts.

To assess how material the effect of changes in coverage on changes of litigation risk is, in Figure 1 we plot the expected probability of being involved in litigation events from models (2) and (4) in Table III for levels of coverage ranging from the 5th to the 95th percentile. For ease of interpretation we re-state the graphs of the marginal effects in terms of non-logarithmic coverage. The graph shows that the effect of analyst coverage is both economically and statistically significant. For example we know that the unconditional probability of being subject of an Accounting and Auditing Enforcement Release is 1.09\%. The estimated probabilities range from $0.67 \%$ for firms covered by a single analyst to $1.68 \%$ for firms in the 95 th percentile of coverage. The results indicate that a one standard deviation increase of coverage from the mean increases the litigation risk from $1.1 \%$ to $1.43 \%$ (a $30 \%$ increase). For securities class actions the effect is even stronger, with a range of litigation risk from $0.76 \%$ to $3.43 \%$ in the 5 th and the 95 th percentile (compared to an unconditional risk of $2.05 \%$ ). In this case a one standard deviation increase of coverage from the mean generates an increase in litigation risk from $1.82 \%$ to $2.79 \%$ (a $53 \%$ increase).

[Place Table III about here]

[Place Figure 1 about here] 


\section{Analyst Incentives}

An interesting and often overlooked aspect of the literature on financial analysts is the analysis of their incentive structure. Arguably producing accurate information requires both skill and effort, and this is particularly true in the case of discovery of managerial misbehavior. Analysts with stronger incentives should produce higher quality information and have stronger effect on litigation risk.

Incentives can be analyzed at two different levels: personal and institutional. For individual analysts, different contributions in the literature show that analysts are rewarded for generating useful firm-specific information. For example Brown, Call, Clement, and Sharp (2015) surveyed 365 analysts on the most relevant determinants of their compensation. According to the respondents the number one factor is clients and brokers satisfaction votes. It is easy to imagine how highlighting possible accounting irregularities in covered companies may benefit clients and increase analyst appreciation. On a more systematic level Hong and Kubik (2003) show that analysts with higher accuracy are compensated with positive career outcomes.

Financial analysts are employed by brokers and, like any other employee, will focus their efforts according to the indications of their employer. It is well known in the literature that investment banks may use analyst coverage as a tool to cross-sell other services, and there is evidence that historically brokers have skewed their coverage toward the positive side (see, for example, Barber, Lehavy, McNichols, and Trueman, 2006).

To analyze institutional incentives, here we identify a group of brokers who actually have a strong incentive to identify managerial misbehavior: brokers affiliated with institutional investors who have a stake in the covered company (hence "affiliated brokers"). Since in our sample we cannot observe buy-side analysts, we consider brokers affiliated with an institutional investor who owns stocks in the covered company as the best possible proxy. An analyst working for such an institution will likely experience a positive career outcome for highlighting managerial misbehavior that could harm investors. 
Empirically we take the 25 largest brokers in I/B/E/S in terms of number of firms covered in our sample period. We then match these institutions to institutional investors in the Thomson Reuters 13f filings. We label "Affiliated" as a broker that is covering a firm in a certain year while having, at the same time, a positive equity ownership in the same company. Overall, we are able to match 24 out of the 25 institutions, with the remaining one being a pure research outfit without any visible affiliation with an institutional investor. These institutional investors hold positions in $46.79 \%$ of our firm/years observations, with an average stake of $1.4 \%$ (and a median stake of $0.6 \%$ ). We can then divide our coverage variable into an "Affiliated and an "Unaffiliated component and test whether both types of coverage have the same effect on litigation risk. Our assumption is that affiliated brokers have stronger incentive to perform as corporate watchdogs and so affiliated coverage should have stronger marginal effect on litigation risk.

We acknowledge that our measure of affiliated coverage is not perfect, as it is based only on the 25 largest outfits in $\mathrm{I} / \mathrm{B} / \mathrm{E} / \mathrm{S}$. The main constraint is that we can only match institutions between $\mathrm{I} / \mathrm{B} / \mathrm{E} / \mathrm{S}$ and the $13 \mathrm{f}$ filings by name. Outside of the top players this match becomes quite uncertain, especially because I/B/E/S only provides a truncated version of the name. Fortunately, the top 25 players represent $44.6 \%$ of the total supply of coverage during our sample period (in terms of number of firms covered). For the companies in our sample covered by these institutions, the average affiliated coverage is 2.38 analysts (median $=2$ ) and this represent, on average, $26.6 \%$ of the total coverage they receive (median $=20 \%$ ). So while we acknowledge that our measure of affiliated coverage likely underestimates the real value, we can also conclude that it has economic significance in terms of coverage.

The results in our analysis are reported in Table IV and confirm the intuition that institutional incentives play a role as the marginal effect of affiliated coverage is clearly stronger than that of unaffiliated analysts. One could argue that this effect may capture a firm selection effect: institutional investors may refuse to invest in opaque firms. The reduced institutional ownership would translate, given our methodology, in a lack of affiliated coverage for firms for which analysts in general may be unable to develop useful information. To minimize this confounding factor we 
repeat the analysis on the subset of firms with affiliated coverage (models 4 - 6). The effect on this sub-sample is even stronger. Figure 2 plots the marginal effect of the two types of coverage on estimated litigation risk.

\section{[Place Table IV about here]}

\section{[Place Figure 2 about here]}

\section{Identification}

While our baseline results are consistent with our hypothesis that financial analysts act as corporate watchdogs, an important concern is that coverage decisions are not random. Unobservable firm heterogeneity correlated with both analyst coverage and the probability of litigation could bias our results. Specifically, we know that the SEC has to make active decisions about the allocation of its scarce investigative resources, and that tort lawyers decide which firms to sue based on an estimate of success probability and potential gains of a class action. Therefore it is not inconceivable that the same unobserved factors that drive these decisions may also drive the interest of financial analysts in covering a specific firm. For example an untimely declaration of the CEO could spark the interest both of the SEC and of the community of financial analysts.

In this section we adopt an identification strategy based on a difference-in-differences (DID) around exogenous reductions in analyst coverage due to mergers and closures of brokerage houses. Hong and Kacperczyk (2010) argue that when two brokerage houses merge, all the stocks firms that were previously covered by both houses will experience an exogenous drop of one in analyst coverage due to the fact that the new resulting entity will provide a single forecast for the firms. Similarly Kelly and Ljungqvist (2012) argue that the closure of brokerage houses produces a similar exogenous shock for all the firms that were covered by the now disappeared entity. This identification strategy has been used by a number of authors. Literature has tied a drop in analysts coverage to changes in innovation policy (He and Tian, 2013), corporate investments (Derrien and Kecskés, 
2013), corporate governance (Chen, Harford, and Lin, 2015) and the cost of debt (Derrien, Kecskés, and Mansi, 2016) among others.

The application of this quasi-natural experiment to our setting is not straightforward due to the discrete (and sparse) nature of our outcome variable (litigation event). A possible workaround is to analyze the effect of the drop in coverage on the probability of being involved in litigation event (litigation risk) rather than counting the events themselves. We first estimate the litigation risk with a probit model similar to our base specification where the probability of a litigation event is modelled on firm characteristics and accounting-based proxy variables for managerial misbehavior. After obtaining the estimated litigation risk, we then analyze the change in litigation risk around the exogenous drop in coverage caused by the closure or merger of brokerage firms. ${ }^{3}$ Due to the fact that it may take some time for fraud to be discovered, we consider both short-termand long-term changes in litigation risk where short-term is defined as the change in litigation risk between the year following the broker closure/merger $(T+1)$ and the average of the three years prior to it $(T-3$ to $T-1)$, and long-term is defined as the change in litigation risk between the three years after the closure/merger $(T+1$ to $T+3)$ and the three years prior to it.

Since other time-related factors could affect this change, we build a control sample by matching every firm that is affected by the closure/merger of a brokerage house with a firm with similar characteristics but unaffected by the event. We explore three different matching strategies. First of all we consider the closest neighbor, from the same industry, in terms of Mahalanobis distance based on all the firm characteristics described in Table I. As a second possibility we also consider the closest neighbor in terms of Mahalanobis distance based on firm characteristics and accounting-based proxies for managerial misbehavior. ${ }^{4}$ Finally we implement a third matching strategy based on a propensity score model estimated on firm characteristics and proxies for managerial misbehavior. In all matching strategies every observation in the treated sample is

\footnotetext{
${ }^{3}$ We thank François Derrien and Jarrad Harford for sharing the list of brokerage disappearances with us. See Derrien and Kecskes (2013) and Chen, Harford, and Lin (2015) for a detailed description of the selection process.

${ }^{4}$ Abadie and Imbens $(2006,2011)$ show that nearest-neighbor matching estimators are not consistent when matching on two or more continuous covariates and propose a bias-corrected estimator that is consistent. Here we implement their suggestion and report the bias-corrected estimator.
} 
matched with observations from the same period and the same industry (Fama and French 12). We also consider an alternative version of these matches where every treated observation is matched with the five closest neighbors.

From Table V we see that firms affected by an exogenous drop in analyst coverage (treated) experience a significant drop in litigation risk compared to the control firms. The reduction is in the range of $0.09 \%$ to $0.20 \%$. Considering that the average treated firm is covered by 16 analysts (with a standard deviation of 8), our results suggest that a drop in coverage of one standard deviation would lead to a decrease in litigation risk of $0.7 \%-1.6 \%$. This magnitude is remarkably similar to what we measured with our baseline model in Table III.

\section{Discipline or Pressure?}

We need to acknowledge that our interpretation of the empirical evidence so far may have been too optimistic. We argue that the increased litigation risk for firms covered by a larger number of analysts is due to the disciplining role of analysts. But what if it was, in fact, a result of increased managerial misbehavior due to the intense pressure to meet short-term goals? He and Tian (2013) show that firms covered by more analysts tend to invest less in innovation, and the authors attribute this to the pressure of having to meet short term expectations. Irani and Oesch (2016) show that while analysts increase accounting quality they also incentivize more aggressive forms of real earnings manipulation.

Distinguishing between discipline and pressure hypotheses is intrinsically difficult as we cannot observe managerial misbehavior directly but only litigation events associated with it. The identification strategy that we suggest here is based on time- and cross-sectional variations in managerial entrenchment. Highly entrenched managers are less likely to feel the pressure to perform as they are less likely to be punished in the case of bad performance. An interesting and critical feature of this identification strategy is that discipline and pressure hypotheses lead to two opposite empirical predictions. If analysts' activity lead to increased pressure we should observe a weaker effect of coverage on litigation risk for highly entrenched CEOs as these managers have no 
pressure to manipulate earnings to outperform. On the other side if analysts' activity leads to increased discipline we should observe a stronger effect of coverage on litigation risk for firms with entrenched managers, the reason being that in these firms the information on managerial misbehavior produced by analysts is particularly valuable to (small) shareholders who are more exposed to expropriation risk one as mechanisms of internal governance usually fails to discipline entrenched managers (Hermalin and Weisbach, 1998; Ryan and Wiggins, 2004). In our identification strategy we model managerial entrenchment looking at governance quality (as proxied by the governance index developed by Gompers, Ishii, and Metrick (2003) and at the presence of large institutional investors.

\subsection{Governance Index}

First we look at the Governance index from Gompers, Ishii, and Metrick (2003). ${ }^{5}$ This index ranks companies of the S\&P 1500 on a scale from 1 to 24 based on the presence of different provisions that limit shareholder rights (increase managerial entrenchment). A high value of the index indicates high managerial entrenchment. The index is available only from 1990 to 2006, therefore we limit this part of our analysis to this sub-period.

In order to distinguish between discipline and pressure we augment our base model with an interaction between $(\log )$ coverage and an indicator variable for firms-years characterized by higher managerial entrenchment (those with a value of the Governance index higher than the median value of 9).

$$
\begin{gathered}
\operatorname{Pr}\left(F_{i t}=1\right)=\Phi\left(\alpha+\beta \text { Coverage }_{i t}+\text { SEntrenched }_{i t}+\text { _Coverage }_{i t} *\right. \\
\text { Entrenched } \left._{i t}+\gamma \text { Controls }_{i t}+\text { Year }_{t}+\text { Industry }_{k}\right)
\end{gathered}
$$

A positive interaction coefficient $\lambda$ would indicate that the positive effect of coverage on

\footnotetext{
${ }^{5}$ We thank the authors for making this data available.
} 
litigation risk is stronger for firms with highly entrenched managers, supporting the disciplining hypothesis. A negative coefficient, on the other side, would indicate a lower effect for these firms and would thus support the pressure hypothesis. Table VI reports the results. The results indicate that analyst coverage have a stronger effect on firms with highly entrenched managers as shown by the positively significant interaction terms. Figure 3 plots the marginal effect of coverage on the probability of being involved in a litigation event for the two groups of firms using the estimated coefficients of model (3) in Table VI. We see that a high level of coverage increases the litigation risk for both groups of firms, but the effect is materially stronger in firms with higher managerial entrenchment, supporting our disciplining hypothesis.

\section{[Place Table VI about here]}

\section{[Place Figure 3 about here]}

\subsection{Institutional Ownership}

The previous analysis is somewhat limited by the availability of the governance index. In order to provide a more general and robust result here we replicate our experiment considering that the absence of large institutional investors can also provide an alternative source of managerial entrenchment. Institutional investors have both incentives and the power to discipline management due the size of their investments (Hartzell and Starks, 2003; Demiralp, D’Mello, Schlingemann, and Subramaniam, 2011; McCahery, Sautner, and Starks, 2016). Hence managers are less entrenched in firms with more institutional investors. We proxy the relevance of large institutional investors by looking at the share of stocks held by Institutional investors (according to the $13 \mathrm{f}$ filings) and the number of institutional shareholders of the company with holdings larger than $2 \%$. For sake of comparability with the previous analysis we split firm/year observations in two groups and define "Entrenched" as observations with the share of institutional ownership (or number of 
institutions with holdings larger than $2 \%$ ) that is below the median value.

As before we argue that if the effect of coverage on litigation risk is due to additional discipline, it should be stronger for firms with highly entrenched managers. Vice versa if the effect is due to the additional pressure to meet short term earnings goals, it should register stronger for firms where institutional investors expect managers to meet the short term earnings benchmarks.

Results in Table VII confirm our previous findings. The interaction term between coverage and entrenched is positive, indicating that the activity offinancial analysts has a stronger (positive) effect on litigation risk for firms with entrenched managers. The marginal plots in Figure 4 show that the effect is material.

\section{[Place Table VII about here]}

\section{[Place Figure 4 about here]}

\section{Conclusion}

In this paper we investigate the role of financial analysts as corporate watchdogs. Prior research shows that firms covered by a larger number of analysts produce higher quality accounting information, and in this paper we show that this effect is due to an increased probability of being involved in litigation events such as SEC investigations or securities class actions. We show that after controlling for a number of firm characteristics and for observable signs of managerial misbehavior, a standard deviation increase in analyst coverage increase litigation risk by $30 \%-53 \%$. We also show that the effect is significantly stronger for brokers affiliated with institutional investors who own a stake in the covered company.

Since analyst coverage decisions are not random our results could be an artifact of some unobservable factors. We address this issue by using a quasi-natural experiment based on 
exogenous shocks to coverage due to mergers and closure of brokerage houses. Ourmain result is confirmed both in significance and size.

We then address a possible alternative interpretation of our main empirical finding. Some authors have argued that analysts may exert pressure on the management to meet short term goals. If this is true the increase in litigation risk for firms covered by a larger number of analysts may be due to the additional incentive to misbehave, rather than by the additional disciplining. We address this issue by exploiting time-series and cross-sectional variations in managerial entrenchment. We argue that while the discipline hypothesis predicts stronger effect of coverage on litigation risk for firms with highly entrenched managers (as mechanisms of internal governance usually fails in these circumstances) the pressure hypothesis leads to the opposite prediction as highly entrenched managers cannot be easily punished for underperforming.

Our empirical results confirm the discipline hypothesis: analyst coverage increases the probability of a firm to be involved in a litigation event, especially in firms with highly entrenched managers. At least in this case we find no evidence of the so-called "dark side" of analyst coverage.

This result sheds light on an important aspect of financial analysts' activity. While the previous literature has shown that analysts can provide incentives for a more virtuous behavior of company executives, here we identify a specific channel for this effect: the increase in the probability of litigation. 


\section{References}

Agrawal, A., Knoeber, C. R., 1996. Firm performance and mechanisms to control agency problems between managers and shareholders. Journal of Financial and Quantitative Analysis 31(3), 377-397.

Arena, M., Ferris, S., 2007. When managers bypass shareholder approval of board appointments: Evidence from the private security market. Journal of Corporate Finance 13(4), 485-510.

Barber, B. M., Lehavy, R., McNichols, M., Trueman, B., 2006. Buys, holds, and sells: The distribution of investment banks' stock ratings and the implications for the profitability of analysts' recommendations. Journal of Accounting and Economics 41(1), 87-117.

Bartov, E., Givoly, D., Hayn, C., 2002. The rewards to meeting or beating earnings expectations. Journal of Accounting and Economics 33(2), 173-204.

Bhojraj, S., Hribar, P., Picconi, M., McInnis, J., 2009. Making sense of cents: An examination of firms that marginally miss or beat analyst forecasts. Journal of Finance 64(5), 2361-2388.

Bhushan, R., 1989. Firm characteristics and analyst following. Journal of Accounting and Economics 11(2), 255-274.

Brown, L. D., Call, A. C., Clement, M. B., Sharp, N. Y., 2015. Inside the black box of sell-side financial analysts. Journal of Accounting Research 53(1), 1-47.

Chen, T., Harford, J., Lin, C., 2015. Do analysts matter for governance? Evidence from natural experiments. Journal of Financial Economics 115(2), 383-410.

Cremers, K., Nair, V. B., 2005. Governance mechanisms and equity prices. Journal of Finance 60(6), 2859-2894.

Dechow, P. M., Sloan, R. G., Sweeney, A. P., 1995. Detecting earnings management. Accounting Review, 193-225.

Demiralp, I., D’Mello, R., Schlingemann, F., Subramaniam, V., 2011. Are there monitoring benefits to institutional ownership? Evidence from seasoned equity offerings. Journal of Corporate Finance 17(1), 1340-1359.

Derrien, F., Kecsk'es, A., 2013. The real effects of financial shocks: Evidence from exogenous changes in analyst coverage. Journal of Finance 68(4), 1407-1440.

Derrien, F., Kecsk'es, A., Mansi, S., 2016. Information asymmetry, the cost of debt, and credit events: Evidence from quasi-random analyst disappearances. Journal of Corporate Finance 39(4), 295-311.

Dyck, A., Morse, A., Zingales, L., 2010. Who blows the whistle on corporate fraud? Journal of Finance 65(6), 2213-2253. 
Gillan, S. L., Hartzell, J. C., Starks, L. T., 2011. Tradeoffs in corporate governance: Evidence from board structures and charter provisions. Quarterly Journal of Finance 1(4), 1667-1705.

Gompers, P., Ishii, J., Metrick, A., 2003. Corporate governance and equity prices. Quarterly Journal of Economics 118(1), 107-155.

Graham, J. R., Harvey, C. R., Rajgopal, S., 2005. The economic implications of corporate financial reporting. Journal of Accounting and Economics 40(1), 3-73.

Hartzell, J. C., Starks, L. T., 2003. Institutional investors and executive compensation. Journal of Finance 58(6), 2351-2374.

He, J. J., Tian, X., 2013. The dark side of analyst coverage: The case of innovation. Journal of Financial Economics 109(3), 856-878.

Hermalin, B. E., Weisbach, M. S., 1998. Endogenously chosen boards of directors and their monitoring of the CEO. American Economic Review 88(1), 96-118.

Hong, H., Kacperczyk, M., 2010. Competition and bias. Quarterly Journal of Economics 125(4), $1683-1725$.

Hong, H., Kubik, J. D., 2003. Analyzing the analysts: Career concerns and biased earnings forecasts. Journal of Finance 58(6), 313-351.

Irani, R. M., Oesch, D., 2013. Monitoring and corporate disclosure: Evidence from a natural experiment. Journal of Financial Economics 109(2), 398-418.

Irani, R. M., Oesch, D., 2016. Analyst coverage and real earnings management: Quasiexperimental evidence. Journal of Financial and Quantitative Analysis 51(2), 589-627.

Jensen, M., Meckling, W. H., 1976. Theory of the firm: Managerial behavior, agency costs and ownership structure. Journal of Financial Economics 3(4), 305-360.

Jones, J. J., 1991. Earnings management during import relief investigations. Journal of Accounting Research 29(2), 193-228.

Karpoff, J. M., Lee, D. S., Martin, G. S., 2008. The cost of firms of cooking the books. Journal of Financial and Quantitative Analysis 43(3), 581-611.

Kedia, S., Philippon, T., 2009. The economics of fraudulent accounting. Review of Financial Studies 22(6), 2169-2199.

Kelly, B., Ljungqvist, A., 2012. Testing asymmetric-information asset pricing models. Review of Financial Studies 25(5), 1366-1413.

Matsunaga, S. R., Park, C. W., 2001. The effect of missing a quarterly earnings benchmark on the CEO's annual bonus. Accounting Review 76(3), 313-332.

McCahery, J. A., Sautner, Z., Starks, L. T., 2016. Behind the scenes: The corporate governance 
preferences of institutional investors. Journal of Finance 71(6), 2905-2932.

McNichols, M., O'Brien, P. C., 1997. Self-selection and analyst coverage. Journal of Accounting Research 35, 167-199.

Miller, G. S., 2006. The press as a watchdog for accounting fraud. Journal of Accounting Research 44(5), 1001-1033.

O'Brien, P., Bhushan, R., 1990. Analyst following and institutional ownership. Journal of Accounting Research 28(1), 55-76.

Piotroski, J. D., Roulstone, D. T., 2004. The influence of analysts, institutional investors, and insiders on the incorporation of market, industry, and firm-specific information into stock prices. The Accounting Review 79(4), 1119-1151.

Roychowdhury, S., 2006. Earnings management through real activities manipulation. Journal of Accounting and Economics 42(3), 335-370.

Ryan, H. E., Wiggins, R. A., 2004. Who is in whose pocket? Director compensation, board independence, and barriers to effective monitoring. Journal of Financial Economics 73(3), 497-524.

Shleifer, A., Vishny, R. W., 1997. A survey of corporate governance. Journal of Finance 52(2), 737-783.

Skinner, D. J., Sloan, R. G., 2002. Earnings surprises, growth expectations, and stock returns or don't let an earnings torpedo sink your portfolio. Review of Accounting Studies 7(2-3), 289312 .

Yu, F., 2008. Analyst coverage and earnings management. Journal of Financial Economics $88(2), 245-271$.

Zang, A. Y., 2012. Evidence on the trade-off between real activities manipulation and accrualbased earnings management. Accounting Review 87(2), 675-703. 


\section{Table I: Variable Definitions}

This table contains the definition of all the variables used throughout the paper

\section{Firm Characteristics}

$\begin{array}{ll}\text { Coverage } & \text { Number of analysts following a company at the beginning of the fiscal year (from } \\ & \text { IBES Summary File). Within regression frameworks we use the natural logarithm } \\ \text { of Coverage indicated as Log(Coverage). } & \text { Total Assets (Compustat AT).Within regression frameworks we use the natural } \\ \text { Size } & \text { logarithm of Size indicated as Log(Size). } \\ \text { Tobin's } Q & \text { Market value of assets divided by book value of assets (AT). Market value of } \\ & \text { assets is calculated as Total Assets (AT) minus book value of common equity } \\ & \text { (CEQ) and deferred taxes (TXDB) plus market value of equity. Market value } \\ & \text { of equity is defined as the product of market price at the ending of the fiscal } \\ & \text { period (PRCC F) and the number of common shares outstanding (CSHO). } \\ \text { Leverage } & \text { Long-Term Debt (DLTT) plus Debt in Current Liabilities (DLC) divided by Total } \\ \text { PPE } & \text { Assets (AT). } \\ \text { POA } & \text { Property, Plant and Equipment (PPENT) divided by Total Assets (AT). } \\ \text { CF Volatility } & \text { Operating Income Before Depreciation (OIBDP) divided by Total Assets (AT). } \\ \text { Ext. Financing } & \text { Is the time series volatility of operating cash flows over the entire sample. } \\ & \text { Is the sum of net equity and net debt issues. Net equity issue is defined as the } \\ & \text { change in book value of equity minus change in retained earnings (RE) divided by } \\ & \text { Total Assets (AT). Book value of equity is defined as total assets (AT) minus total } \\ \text { liabilities (LT) and preferred stocks (PSTKL) plus deferred taxes and investment } \\ \text { tax credit (TXDITC) and convertible debt (DCVT). When the value for preferred } \\ \text { stocks is missing it is replaced with the redemption value of preferred stocks } \\ \text { (PSTKRV). Net debt issue is defined as change in total assets minus change in } \\ \text { book value of equity divided by total assets (AT). }\end{array}$

Managerial Misbehavior

Abn. Accruals

Absolute value of abnormal discretionary accruals (See Appendix for the calculation).

Abn. Cash Flows Is the abnormal value of cash flows (See Appendix for the calculation).

Abn. Production Is the abnormal value of production costs (See Appendix for the calculation).

Abn. Expenses Is the abnormal value of discretionary expenses (See Appendix for the calculation).

Governance Quality

G-Index Governance quality index from Gompers, Ishii and Metrick (2003).

Institutional Percentage of common shares owned by institutional investors (from 13f Filings).

Own 2\% Number of institutional investors with equity holding above $2 \%$ (from $13 \mathrm{f}$ Filings).

Table I: Variable Definitions 
Table II: Descriptive Statistics

This table reports mean and standard deviation for the variables used in the empirical analysis. Descriptive statistics are calculated for three subsamples. Firm/Year observations not involved in any litigation event (1988 - 2016), observations where an AAER event occurred (1988 - 2013) and observations where a security class action occurred (1996 - 2016). T tests are calculated for the significance of the difference of the mean values for firms involved in litigation events and firms not involved in litigation events. T-Statistics are displayed in parentheses. (***,** and $*$ indicate significance at the $1 \%, 5 \%$ and $10 \%$ respectively)

\begin{tabular}{|c|c|c|c|c|c|c|}
\hline \multirow[t]{2}{*}{ Num. Obs. } & \multicolumn{2}{|c|}{$\begin{array}{c}\text { Not Involved } \\
59,032 \\
\end{array}$} & \multicolumn{2}{|c|}{$\begin{array}{c}\text { AAER } \\
588\end{array}$} & \multicolumn{2}{|c|}{$\begin{array}{c}\text { Securities Class Action } \\
994\end{array}$} \\
\hline & Mean & S.D. & Mean & S.D. & Mean & S.D. \\
\hline Coverage & 8.6 & 7.4 & $\begin{array}{c}12.1 * * * \\
(9.901)\end{array}$ & 8.6 & $\begin{array}{c}12.1 * * * \\
(12.824)\end{array}$ & 8.5 \\
\hline Size & 11,937 & 79,377 & $\begin{array}{l}26369 * * * \\
(3.288)\end{array}$ & 106,128 & $\begin{array}{l}57099.8 * * * \\
(5.387)\end{array}$ & 264,140 \\
\hline Tobin's Q & 1.698 & 1.1453 & $\begin{array}{l}2.077 * * * \\
(5.518)\end{array}$ & 1.662 & $\begin{array}{l}1.831 * * * \\
(3.239)\end{array}$ & 1.287 \\
\hline Leverage & 0.231 & 0.1842 & $\begin{array}{l}0.242 \\
(1.403)\end{array}$ & 0.192 & $\begin{array}{l}0.22 * \\
(-1.795)\end{array}$ & 0.192 \\
\hline PPE & 0.287 & 0.2513 & $\begin{array}{c}0.184 * * * \\
(-13.951)\end{array}$ & 0.176 & $\begin{array}{l}0.21 * * * \\
(-11.472)\end{array}$ & 0.208 \\
\hline ROA & 0.112 & 0.1071 & $\begin{array}{c}0.107 \\
(-1.580)\end{array}$ & 0.084 & $\begin{array}{c}0.07 * * * \\
(-8.275)\end{array}$ & 0.160 \\
\hline CF Volatility & 0.082 & 0.4470 & $\begin{array}{l}0.084 \\
(0.553)\end{array}$ & 0.060 & $\begin{array}{l}0.104 * * * \\
(5.251)\end{array}$ & 0.115 \\
\hline Ext. Financing & 0.056 & 0.1560 & $\begin{array}{l}0.125 * * * \\
(8.543)\end{array}$ & 0.193 & $\begin{array}{l}0.064 \\
(1.292)\end{array}$ & 0.181 \\
\hline Inst. Ownership & 0.576 & 0.2864 & $\begin{array}{c}0.68 * * * \\
(10.739)\end{array}$ & 0.233 & $\begin{array}{l}0.664 * * * \\
(10.430)\end{array}$ & 0.264 \\
\hline Abn. Accruals & 0.068 & 0.0732 & $\begin{array}{c}0.079 * * \\
(2.526)\end{array}$ & 0.098 & $\begin{array}{l}0.094 * * * \\
(7.932)\end{array}$ & 0.100 \\
\hline Abn. Cash Flows & -0.011 & 0.1971 & $\begin{array}{c}0.007 * \\
(1.935)\end{array}$ & 0.224 & $\begin{array}{l}-0.014 \\
(-0.394)\end{array}$ & 0.224 \\
\hline Abn. Production & 0.021 & 0.0961 & $\begin{array}{c}0.019 \\
(-0.344)\end{array}$ & 0.108 & $\begin{array}{c}0.016 \\
(-1.130)\end{array}$ & 0.129 \\
\hline Abn. Expenses & -0.022 & 0.1861 & $\begin{array}{c}-0.053 * * * \\
(-3.308)\end{array}$ & 0.227 & $\begin{array}{r}-0.016 \\
(0.974)\end{array}$ & 0.208 \\
\hline
\end{tabular}


Table III: Analysts Coverage and Litigation Risk

This table reports probit estimations where the dichotomous dependent variable is a litigation event. Models 1 - 2 use data from 1988 to 2013 and consider AAER as litigation events. Models 3 - 4 use data from 1996 to 2016 and consider Shareholders Class Actions as litigation events. Models 5 - 6 consider both forms of litigation and use data from 1988 to 2016. All the independent variables are described in Table I. All models include time and industry fixed effects and standard errors are clustered at the firm level. T-Statistics are displayed in parentheses. $(* * *, * *$ and $*$ indicate significance at the $1 \%, 5 \%$ and $10 \%$ respectively).

\begin{tabular}{|c|c|c|c|c|c|c|}
\hline & (1) & (2) & (3) & (4) & (5) & (6) \\
\hline & \multicolumn{2}{|c|}{ AAER } & \multicolumn{2}{|c|}{ Securities Class Action } & \multicolumn{2}{|c|}{ Litigation Event } \\
\hline Log (Coverage) & $\begin{array}{c}0.104 * * \\
(2.555)\end{array}$ & $\begin{array}{c}0.120 * * * \\
(2.919)\end{array}$ & $\begin{array}{c}0.219 * * * \\
(9.322)\end{array}$ & $\begin{array}{c}0.203 * * * \\
(8.708)\end{array}$ & $\begin{array}{c}0.181 * * * \\
(7.863)\end{array}$ & $\begin{array}{c}0.175 * * * \\
(7.671)\end{array}$ \\
\hline Log (Size) & $\begin{array}{c}0.094 * * * \\
(4.427)\end{array}$ & $\begin{array}{c}0.089 * * * \\
(4.046)\end{array}$ & $\begin{array}{c}0.066 * * * \\
(5.399)\end{array}$ & $\begin{array}{c}0.083 * * * \\
(6.778)\end{array}$ & $\begin{array}{c}0.081 * * * \\
(6.689)\end{array}$ & $\begin{array}{c}0.090 * * * \\
(7.341)\end{array}$ \\
\hline Tobin's Q & $\begin{array}{c}0.022 \\
(1.080)\end{array}$ & $\begin{array}{c}0.043 * * \\
(2.169)\end{array}$ & $\begin{array}{c}-0.021 \\
(-1.515)\end{array}$ & $\begin{array}{l}-0.032 * * \\
(-2.192)\end{array}$ & $\begin{array}{c}0.003 \\
(0.240)\end{array}$ & $\begin{array}{c}0.005 \\
(0.355)\end{array}$ \\
\hline Leverage & $\begin{array}{c}0.206 \\
(1.245)\end{array}$ & $\begin{array}{c}0.129 \\
(0.759)\end{array}$ & $\begin{array}{c}-0.008 \\
(-0.088)\end{array}$ & $\begin{array}{c}-0.030 \\
(-0.316)\end{array}$ & $\begin{array}{c}0.058 \\
(0.620)\end{array}$ & $\begin{array}{c}0.020 \\
(0.204)\end{array}$ \\
\hline PPE & $\begin{array}{c}-0.898 * * * \\
(-3.382)\end{array}$ & $\begin{array}{c}-0.884 * * * \\
(-3.320)\end{array}$ & $\begin{array}{l}-0.225 * * \\
(-2.124)\end{array}$ & $\begin{array}{l}-0.202 * \\
(-1.858)\end{array}$ & $\begin{array}{c}-0.471 * * * \\
(-3.874)\end{array}$ & $\begin{array}{c}-0.464 * * * \\
(-3.787)\end{array}$ \\
\hline ROA & $\begin{array}{l}-0.476^{*} \\
(-1.877)\end{array}$ & $\begin{array}{c}-0.238 \\
(-0.814)\end{array}$ & $\begin{array}{c}-1.212 * * * \\
(-10.117)\end{array}$ & $\begin{array}{c}-0.971 * * * \\
(-6.991)\end{array}$ & $\begin{array}{c}-1.058^{* * *} \\
(-8.736)\end{array}$ & $\begin{array}{c}-0.849 * * * \\
(-5.854)\end{array}$ \\
\hline CF Volatility & $\begin{array}{c}0.009 \\
(0.273)\end{array}$ & $\begin{array}{c}0.011 \\
(0.410)\end{array}$ & $\begin{array}{l}0.024^{*} \\
(1.698)\end{array}$ & $\begin{array}{c}0.021 \\
(1.565)\end{array}$ & $\begin{array}{l}0.025^{*} \\
(1.795)\end{array}$ & $\begin{array}{l}0.022 * \\
(1.648)\end{array}$ \\
\hline Ext. Financing & $\begin{array}{c}0.587 * * * \\
(5.537)\end{array}$ & $\begin{array}{c}0.680 * * * \\
(6.018)\end{array}$ & $\begin{array}{c}-0.108 \\
(-1.219)\end{array}$ & $\begin{array}{c}-0.241 * * * \\
(-2.789)\end{array}$ & $\begin{array}{c}0.206 * * * \\
(2.715)\end{array}$ & $\begin{array}{l}0.142 * \\
(1.867)\end{array}$ \\
\hline Inst. Ownership & $\begin{array}{c}0.517 * * * \\
(3.644)\end{array}$ & $\begin{array}{c}0.504 * * * \\
(3.549)\end{array}$ & $\begin{array}{c}-0.002 \\
(-0.038)\end{array}$ & $\begin{array}{c}0.035 \\
(0.581)\end{array}$ & $\begin{array}{c}0.189 * * * \\
(2.806)\end{array}$ & $\begin{array}{c}0.215^{* * *} \\
(3.189)\end{array}$ \\
\hline Abn. Accruals & & $\begin{array}{c}-0.307 \\
(-1.014)\end{array}$ & & $\begin{array}{c}1.268 * * * \\
(7.834)\end{array}$ & & $\begin{array}{c}0.846^{* * *} \\
(5.133)\end{array}$ \\
\hline Abn. Cash Flows & & $\begin{array}{c}-0.930 * * * \\
(-3.287)\end{array}$ & & $\begin{array}{l}-0.479 * * \\
(-2.571)\end{array}$ & & $\begin{array}{c}-0.627 * * * \\
(-3.611)\end{array}$ \\
\hline Abn. Production & & $\begin{array}{c}-0.158 \\
(-0.847)\end{array}$ & & $\begin{array}{l}-0.240 * \\
(-1.893)\end{array}$ & & $\begin{array}{c}-0.254 * * \\
(-2.088)\end{array}$ \\
\hline Abn. Expenses & & $\begin{array}{l}-0.359 * \\
(-1.810)\end{array}$ & & $\begin{array}{c}0.041 \\
(0.363)\end{array}$ & & $\begin{array}{c}-0.180 \\
(-1.528)\end{array}$ \\
\hline Constant & $\begin{array}{c}-5.063 * * * \\
(-11.015) \\
\end{array}$ & $\begin{array}{c}-5.087 * * * \\
(-10.931)\end{array}$ & $\begin{array}{c}-3.154 * * * \\
(-17.712)\end{array}$ & $\begin{array}{c}-3.402 * * * \\
(-18.596)\end{array}$ & $\begin{array}{c}-2.719 * * * \\
(-17.211)\end{array}$ & $\begin{array}{c}-2.887 * * * \\
(-17.818)\end{array}$ \\
\hline Year and Industry FE & $\mathrm{Y}$ & $\mathrm{Y}$ & $\mathrm{Y}$ & $\mathrm{Y}$ & $\mathrm{Y}$ & $\mathrm{Y}$ \\
\hline Clustered SE & $\mathrm{Y}$ & $\mathrm{Y}$ & $\mathrm{Y}$ & $\mathrm{Y}$ & $\mathrm{Y}$ & $\mathrm{Y}$ \\
\hline $\mathbf{N}$ & 48,829 & 48,829 & 48,469 & 48,469 & 59,313 & 59,313 \\
\hline pseudo R-sq & 0.161 & 0.165 & 0.077 & 0.084 & 0.108 & 0.111 \\
\hline
\end{tabular}


Table IV: Affiliated vs unaffiliated coverage

This table reports probit estimations where the dichotomous dependent variable is a litigation event (AAER or Shareholder Class Action). Our main variables of interest are the (natural log of) affiliated and unaffiliated coverage. Coverage is "affiliated" if the broker is affiliated with an institutional investor with ownership in the covered company. Models (4) to (6) repeat the analysis on the sub-sample of companies where the affiliated coverage is non-zero. All independent variables are described in Table I. All models include time and industry fixed effects and standard errors are clustered at the firm level. T-Statistics are displayed in parentheses. $(* * *, * *$ and $*$ indicate significance at the $1 \%, 5 \%$ and $10 \%$ respectively).

\begin{tabular}{|c|c|c|c|c|c|c|}
\hline \multirow{3}{*}{ Log (Affiliated Cov.) } & (1) & (2) & (3) & (4) & (5) & (6) \\
\hline & \multicolumn{3}{|c|}{ Entire Sample } & \multicolumn{3}{|c|}{ Firms with Affiliated Coverage $>0$} \\
\hline & $\begin{array}{c}0.259^{* * *} \\
(9.598)\end{array}$ & $\begin{array}{c}0.196^{* * *} \\
(6.648)\end{array}$ & $\begin{array}{c}0.190 * * * \\
(6.444)\end{array}$ & $\begin{array}{c}0.387 * * * \\
(9.572)\end{array}$ & $\begin{array}{c}0.326^{* * *} \\
(7.581)\end{array}$ & $\begin{array}{c}0.319^{* * *} \\
(7.438)\end{array}$ \\
\hline Log (Non Affil. Cov.) & $\begin{array}{c}0.151^{* * *} \\
(6.640)\end{array}$ & $\begin{array}{c}0.121 * * * \\
(4.855)\end{array}$ & $\begin{array}{c}0.117 * * * \\
(4.727)\end{array}$ & $\begin{array}{c}0.096^{* * * *} \\
(3.670)\end{array}$ & $\begin{array}{c}0.080 * * * \\
(2.839)\end{array}$ & $\begin{array}{c}0.075^{* * *} \\
(2.677)\end{array}$ \\
\hline Log (Size) & & $\begin{array}{c}0.063 * * * \\
(4.862)\end{array}$ & $\begin{array}{c}0.072 * * * \\
(5.545)\end{array}$ & & $\begin{array}{c}0.064 * * * \\
(3.915)\end{array}$ & $\begin{array}{c}0.073 * * * \\
(4.481)\end{array}$ \\
\hline Tobin's Q & & $\begin{array}{c}-0.005 \\
(-0.331)\end{array}$ & $\begin{array}{c}-0.003 \\
(-0.182)\end{array}$ & & $\begin{array}{c}-0.007 \\
(-0.421)\end{array}$ & $\begin{array}{c}-0.006 \\
(-0.369)\end{array}$ \\
\hline Leverage & & $\begin{array}{c}0.063 \\
(0.674)\end{array}$ & $\begin{array}{c}0.025 \\
(0.262)\end{array}$ & & $\begin{array}{c}0.112 \\
(0.969)\end{array}$ & $\begin{array}{c}0.072 \\
(0.609)\end{array}$ \\
\hline PPE & & $\begin{array}{c}-0.474 * * * \\
(-3.881)\end{array}$ & $\begin{array}{c}-0.465^{* * *} \\
(-3.781)\end{array}$ & & $\begin{array}{c}-0.684 * * * \\
(-4.969)\end{array}$ & $\begin{array}{c}-0.679 * * * \\
(-4.887)\end{array}$ \\
\hline ROA & & $\begin{array}{c}-1.049^{* * *} \\
(-8.704)\end{array}$ & $\begin{array}{c}-0.838^{* * * *} \\
(-5.807)\end{array}$ & & $\begin{array}{c}-1.007^{* * *} \\
(-6.555)\end{array}$ & $\begin{array}{c}-0.898^{* * *} \\
(-4.605)\end{array}$ \\
\hline CF Volatility & & $\begin{array}{c}0.022 \\
(1.622)\end{array}$ & $\begin{array}{c}0.020 \\
(1.474)\end{array}$ & & $\begin{array}{c}0.394 * * * \\
(2.719)\end{array}$ & $\begin{array}{c}0.368 * * * \\
(2.667)\end{array}$ \\
\hline Ext. Financing & & $\begin{array}{c}0.192 * * \\
(2.546)\end{array}$ & $\begin{array}{l}0.129^{*} \\
(1.703)\end{array}$ & & $\begin{array}{c}0.150 \\
(1.627)\end{array}$ & $\begin{array}{c}0.112 \\
(1.186)\end{array}$ \\
\hline Inst. Ownership & & $\begin{array}{c}0.160 * * \\
(2.289)\end{array}$ & $\begin{array}{c}0.186^{* * *} \\
(2.664)\end{array}$ & & $\begin{array}{c}0.099 \\
(1.122)\end{array}$ & $\begin{array}{c}0.134 \\
(1.528)\end{array}$ \\
\hline Abn. Accruals & & & $\begin{array}{c}0.809 * * * \\
(4.927)\end{array}$ & & & $\begin{array}{c}0.693 * * * \\
(3.239)\end{array}$ \\
\hline Abn. Cash Flows & & & $\begin{array}{c}-0.632 * * * \\
(-3.625)\end{array}$ & & & $\begin{array}{c}-0.646^{* * *} \\
(-2.772)\end{array}$ \\
\hline Abn. Production & & & $\begin{array}{c}-0.247^{* *} \\
(-2.033)\end{array}$ & & & $\begin{array}{c}-0.395 * * \\
(-2.401)\end{array}$ \\
\hline Abn. Expenses & & & $\begin{array}{c}-0.170 \\
(-1.438)\end{array}$ & & & $\begin{array}{c}-0.247 \\
(-1.571)\end{array}$ \\
\hline Constant & $\begin{array}{c}-2.338^{* * *} \\
(-21.872) \\
\end{array}$ & $\begin{array}{c}-2.548^{* * *} \\
(-15.666) \\
\end{array}$ & $\begin{array}{r}-2.717 * * * \\
(-16.334) \\
\end{array}$ & $\begin{array}{c}-3.218^{* * *} \\
(-15.695) \\
\end{array}$ & $\begin{array}{l}-3.122 * * * \\
(-12.448)\end{array}$ & $\begin{array}{r}-3.265 * * * \\
(-12.833) \\
\end{array}$ \\
\hline Year and Industry FE & $\mathrm{Y}$ & $\mathrm{Y}$ & $\mathrm{Y}$ & $\mathrm{Y}$ & $\mathrm{Y}$ & $\mathrm{Y}$ \\
\hline Clustered SE & Y & Y & $\mathrm{Y}$ & Y & Y & Y \\
\hline $\mathbf{N}$ & 59,313 & 59,313 & 59,313 & 28,228 & 28,228 & 28,228 \\
\hline pseudo R-sq & 0.095 & 0.110 & 0.113 & 0.077 & 0.095 & 0.098 \\
\hline
\end{tabular}




\section{Table V: Difference-in-Differences Estimation}

The table reports the results of a diff-in-diff estimation of litigation risk changes around an exogenous drop in analyst coverage due to a merger between two brokerage houses or the closure of a brokerage house. Litigation risk is defined as the probability of being involved in a litigation event estimated with a probit model of our litigation events over firm and characteristics and managerial misbehavior proxies detailed in Table I. We consider short-term (Panel A) and long-term (Panel B) change of litigation risk. Short term is defined as the change between the year following the broker closure/merger $(T+1)$ and the average of the three years before $(T-3$ to $T-1)$. Long term is defined as the change between the three years after the closure/merger $(\mathrm{T}+1$ to $\mathrm{T}+3)$ and the three years before. Every treated firm is matched with either one or five control firms from the same period and the same industry (Fama-French 12) based on one of three different matching criteria: a) closest neighbor(s) in terms of Malhanobis distance on firm characteristics; b) closest neighbor(s) in terms of Malhanobis distance on firm characteristics and misbehavior proxies; c) closest neighbor(s) in terms of propensity score estimated on firm characteristics and misbehavior proxies. For every matching strategy we report the average change in litigation risk for treatment and control sample as well as for the difference between the two, our diff-in-diff estimator. T-Statistics are displayed in parentheses. $(* * *, * *$ and $*$ indicate significance at the $1 \%, 5 \%$ and $10 \%$ respectively).

\begin{tabular}{|c|c|c|c|c|c|}
\hline \multicolumn{6}{|l|}{ Panel A: Short Term Effect } \\
\hline & N. of Obs. & Treatment & Control & Diff-in-Diff & t-stat \\
\hline \multicolumn{6}{|l|}{ Closest Neighbor } \\
\hline Matched by firm characteristics & 1740 & 0.431 & 0.611 & -0.180 & $(-2.868)^{* * *}$ \\
\hline Matched by firm and accounting characteristics & 1740 & 0.431 & 0.567 & -0.136 & $(-2.188) * *$ \\
\hline Propensity Score Matching & 1740 & 0.431 & 0.626 & -0.195 & $(-2.948)^{* * *}$ \\
\hline \multicolumn{6}{|l|}{ Closest ten Neighbors } \\
\hline Matched by firm characteristics & 1740 & 0.431 & 0.586 & -0.154 & $(-2.985)^{* * *}$ \\
\hline Matched by firm and accounting characteristics & 1740 & 0.431 & 0.542 & -0.111 & $(-2.137)^{* *}$ \\
\hline Propensity Score Matching & 1740 & 0.431 & 0.660 & -0.229 & $(-4.154)^{* * *}$ \\
\hline \multicolumn{6}{|l|}{ Panel B: Long Term Effect } \\
\hline \multicolumn{6}{|l|}{ Closest Neighbor } \\
\hline Matched by firm characteristics & 1524 & 0.275 & 0.464 & -0.188 & $(-3.211)^{* * *}$ \\
\hline Matched by firm and accounting characteristics & 1524 & 0.275 & 0.405 & -0.130 & $(-2.237)^{* *}$ \\
\hline Propensity Score Matching & 1524 & 0.275 & 0.390 & -0.114 & $(-1.903)^{*}$ \\
\hline \multicolumn{6}{|l|}{ Closest ten Neighbors } \\
\hline Matched by firm characteristics & 1524 & 0.275 & 0.421 & -0.146 & $(-2.996)^{* * *}$ \\
\hline Matched by firm and accounting characteristics & 1524 & 0.275 & 0.367 & -0.092 & $(-1.878)^{*}$ \\
\hline Propensity Score Matching & 1524 & 0.275 & 0.454 & -0.179 & $(-3.535)^{* * *}$ \\
\hline
\end{tabular}




\section{Table VI: Governance Index}

The table shows the results of a probit estimation of the effect of analyst coverage on the probability of litigation for firms with different levels of managerial entrenchment (governance quality). Entrenched is defined as a Gompers et al. (2003) governance index above 9 (the median value in our sample). The analysis is repeated for the entire period (Models 1 - 3) and for the sub-period prior to the changes in governance data reporting introduced by IRRC in 2007 (Models 4 - 6). All the independent variables are described in Table I. All models include time and industry fixed effects and standard errors are clustered at the firm level. T-Statistics are displayed in parentheses. $(* * *, * *$ and $*$ indicate significance at the $1 \%, 5 \%$ and $10 \%$ respectively).

\begin{tabular}{|c|c|c|c|c|c|c|}
\hline \multirow[b]{3}{*}{ Log (Coverage) } & (1) & (2) & (3) & (4) & (5) & (6) \\
\hline & \multicolumn{3}{|c|}{ Entire Period } & \multicolumn{3}{|c|}{ Before 2007} \\
\hline & $\begin{array}{c}0.248^{* * *} \\
(6.555)\end{array}$ & $\begin{array}{c}0.117^{* * * *} \\
(2.911)\end{array}$ & $\begin{array}{c}0.113^{* * *} \\
(2.811)\end{array}$ & $\begin{array}{c}0.244^{* * *} \\
(5.204)\end{array}$ & $\begin{array}{c}0.119^{* *} \\
(2.377)\end{array}$ & $\begin{array}{c}0.120^{* *} \\
(2.406)\end{array}$ \\
\hline Entrenched & $\begin{array}{l}-0.301 * * \\
(-1.984)\end{array}$ & $\begin{array}{l}-0.332 * * \\
(-2.277)\end{array}$ & $\begin{array}{l}-0.327 * * \\
(-2.248)\end{array}$ & $\begin{array}{c}- \\
0.622 * * * \\
(-3.367)\end{array}$ & $\begin{array}{c}- \\
0.656^{* * *} \\
(-3.634)\end{array}$ & $\begin{array}{c}- \\
0.667^{* * *} \\
(-3.656)\end{array}$ \\
\hline Log (Coverage) x Entrenched & $\begin{array}{l}0.104 * \\
(1.712)\end{array}$ & $\begin{array}{l}0.121^{* *} \\
(2.099)\end{array}$ & $\begin{array}{l}0.120^{* *} \\
(2.081)\end{array}$ & $\begin{array}{c}0.237^{* * *} \\
(3.218)\end{array}$ & $\begin{array}{c}0.251^{* * * *} \\
(3.512)\end{array}$ & $\begin{array}{c}0.254^{* * * *} \\
(3.526)\end{array}$ \\
\hline Firm Controls & $\mathrm{N}$ & $\mathrm{Y}$ & $\mathrm{Y}$ & $\mathrm{N}$ & $\mathrm{Y}$ & $\mathrm{Y}$ \\
\hline Misbehavior Controls & $\mathrm{N}$ & $\mathrm{N}$ & $\mathrm{Y}$ & $\mathrm{N}$ & $\mathrm{N}$ & $\mathrm{Y}$ \\
\hline Year FE & $\mathrm{Y}$ & $\mathrm{Y}$ & $\mathrm{Y}$ & $\mathrm{Y}$ & $\mathrm{Y}$ & $\mathrm{Y}$ \\
\hline Industry FE & $\mathrm{Y}$ & $\mathrm{Y}$ & $\mathrm{Y}$ & $\mathrm{Y}$ & $\mathrm{Y}$ & $\mathrm{Y}$ \\
\hline Clustered SE & $\mathrm{Y}$ & $\mathrm{Y}$ & $\mathrm{Y}$ & $\mathrm{Y}$ & $\mathrm{Y}$ & $\mathrm{Y}$ \\
\hline $\mathbf{N}$ & 27,411 & 27,411 & 27,411 & 17,055 & 17,055 & 17,055 \\
\hline pseudo R-sq & 0.104 & 0.122 & 0.123 & 0.134 & 0.156 & 0.156 \\
\hline
\end{tabular}




\section{Table VII: Institutional Ownership}

The table shows the results of a probit estimation of the effect of analyst coverage on the probability of litigation for firms with different levels of managerial entrenchment (institutional ownership). Firm/year observations are labeled Entrenched either if the percentage of shares owned by institutional investors (Models 1 - 3) or the number of institutional investors with holding greater than 2\% (Models $4-6$ ) are below the median value. All the independent variables are described in Table I. All models include time and industry fixed effects and standard errors are clustered at the firm level. T-Statistics are displayed in parentheses. $(* * *, * *$ and $*$ indicate significance at the $1 \%, 5 \%$ and $10 \%$ respectively).

\begin{tabular}{|c|c|c|c|c|c|c|}
\hline \multirow[b]{3}{*}{ Log (Coverage) } & (1) & (2) & (3) & (4) & (5) & (6) \\
\hline & \multicolumn{3}{|c|}{$\%$ of Institutional Ownership } & \multicolumn{3}{|c|}{$\begin{array}{c}\text { N. of Inst. Investors with holding } \\
>2 \%\end{array}$} \\
\hline & $\begin{array}{c}0.208^{* * *} \\
(7.571)\end{array}$ & $\begin{array}{c}0.130^{* * *} \\
(4.454)\end{array}$ & $\begin{array}{c}0.127^{* * *} \\
(4.382)\end{array}$ & $\begin{array}{c}0.205 * * * \\
(8.164)\end{array}$ & $\begin{array}{c}0.136^{* * *} \\
(5.055)\end{array}$ & $\begin{array}{c}0.133^{* * *} \\
(4.965)\end{array}$ \\
\hline Entrenched & $\begin{array}{c}-0.235^{* * *} \\
(-2.950)\end{array}$ & $\begin{array}{c}-0.309^{* * *} \\
(-3.933)\end{array}$ & $\begin{array}{c}-0.317^{* * *} \\
(-4.034)\end{array}$ & $\begin{array}{c}-0.252 * * * \\
(-3.262)\end{array}$ & $\begin{array}{c}-0.316^{* * *} \\
(-4.159)\end{array}$ & $\begin{array}{r}-0.326^{* * *} \\
(-4.293)\end{array}$ \\
\hline $\begin{array}{l}\log (\text { Coverage }) x \\
\text { Entrenched }\end{array}$ & $\begin{array}{c}0.115^{* * *} \\
(3.245)\end{array}$ & $\begin{array}{c}0.134 * * * \\
(3.883)\end{array}$ & $\begin{array}{c}0.132 * * * \\
(3.822)\end{array}$ & $\begin{array}{c}0.124 * * * \\
(3.612)\end{array}$ & $\begin{array}{c}0.132 * * * \\
(3.940)\end{array}$ & $\begin{array}{c}0.132 * * * \\
(3.933)\end{array}$ \\
\hline Firm Controls & $\mathrm{N}$ & $\mathrm{Y}$ & $\mathrm{Y}$ & $\mathrm{N}$ & $\mathrm{Y}$ & $\mathrm{Y}$ \\
\hline Misbehavior Controls & $\mathrm{N}$ & $\mathrm{N}$ & $\mathrm{Y}$ & $\mathrm{N}$ & $\mathrm{N}$ & Y \\
\hline Year FE & Y & Y & Y & Y & Y & Y \\
\hline Industry $\mathbf{F E}$ & $\mathrm{Y}$ & Y & Y & Y & Y & Y \\
\hline Clustered SE & $\mathrm{Y}$ & $\mathrm{Y}$ & Y & Y & $\mathrm{Y}$ & Y \\
\hline $\mathbf{N}$ & 59,313 & 59,313 & 59,313 & 59,313 & 59,313 & 59,313 \\
\hline pseudo R-sq & 0.092 & 0.109 & 0.111 & 0.092 & 0.109 & 0.112 \\
\hline
\end{tabular}




\section{Figure 1: Analyst coverage and litigation risk}

The figure shows the estimated litigation risk (probability of being involved in a litigation event) for levels of (log-) coverage ranging from the 5th to the 95th percentile. Estimations are based on the coefficients of models (2) and (4) in Table III. For ease of interpretation graph is re-scaled on number of analysts (rather than the logarithm). The plot also reports the $95 \%$ confidence intervals for the marginal effects. The unconditional litigation risk is $0.97 \%$ for AAERs and $1.64 \%$ for Securities class actions. Coverage has mean value of 8.69 analysts and a standard deviation of 7.48 .
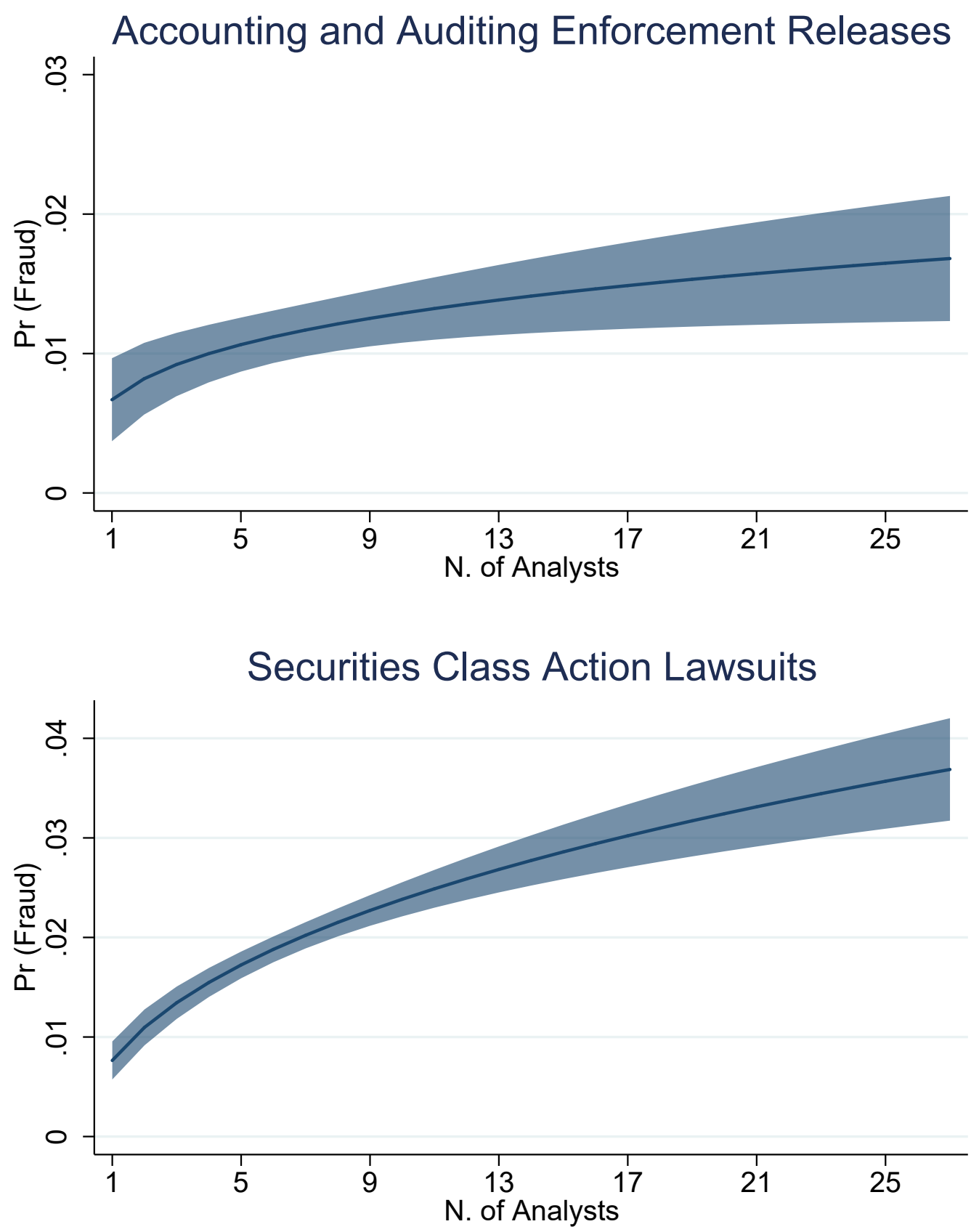


\section{Figure 2: Affiliated coverage and litigation risk}

The figure shows the estimated litigation risk (probability of being involved in a litigation event) for the first ten affiliated and unaffiliated analysts covering a firm. Estimations are based on the coefficients of model (6) in Table IV. For ease of interpretation graph is re- scaled on number of analysts (rather than the logarithm). The plot also reports the $95 \%$ confidence intervals for the marginal effects.
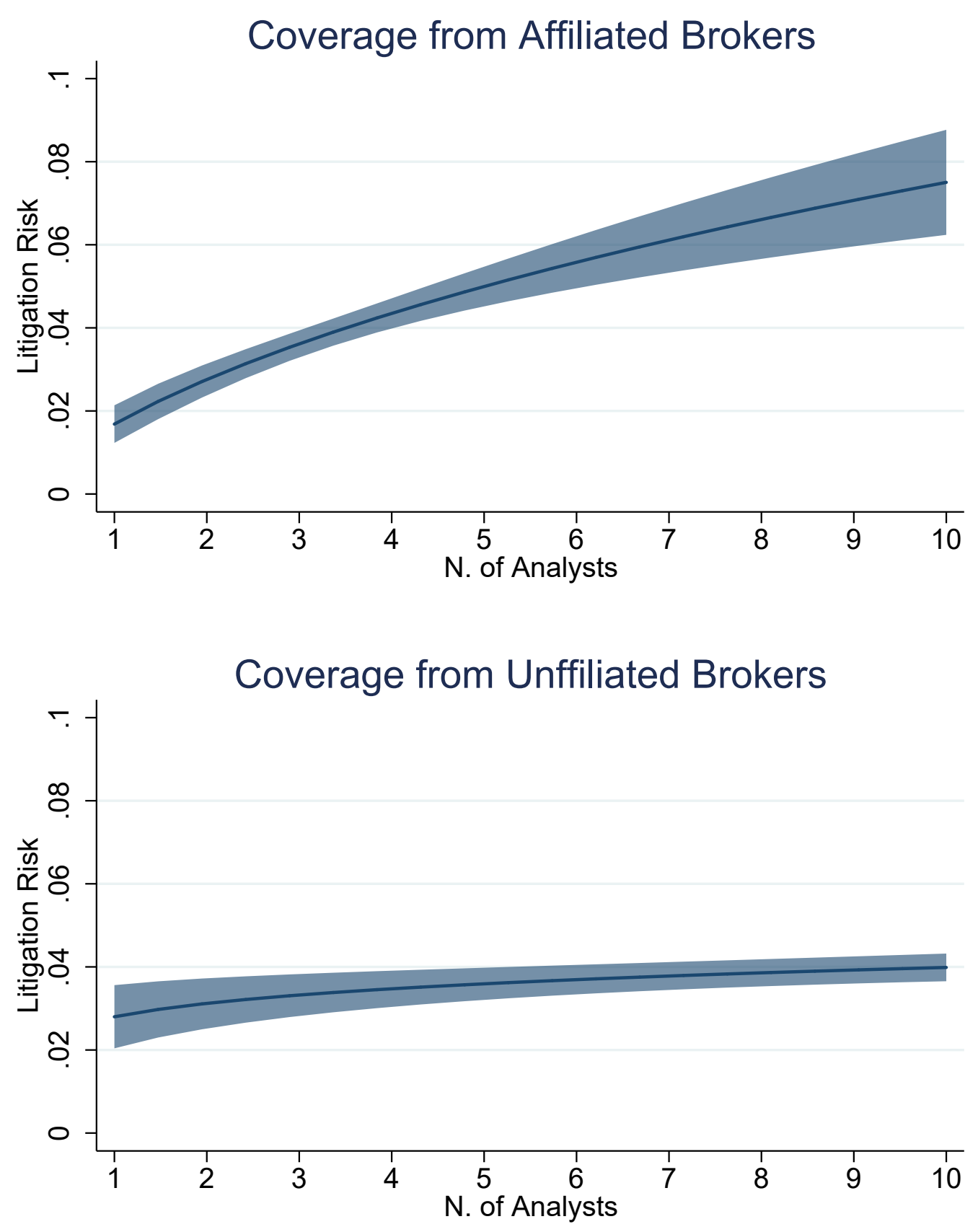


\section{Figure 3: Governance Index}

The figure shows the estimated litigation risk (probability of being involved in a litigation event) for levels of (log-) coverage ranging from the 5th to the 95th percentile. Estimations are based on the coefficients of model (2) and in Table 6 and are reported separately for firms with high and low levels of managerial entrenchment based on the GIM index. For ease of interpretation graph is re-scaled on number of analysts (rather than the logarithm). The plot also reports the 95\% confidence intervals for the marginal effects. The analysis is repeated for the sub-sample of years prior to the changes in IRRC governance data reporting.

\section{Entire Period}
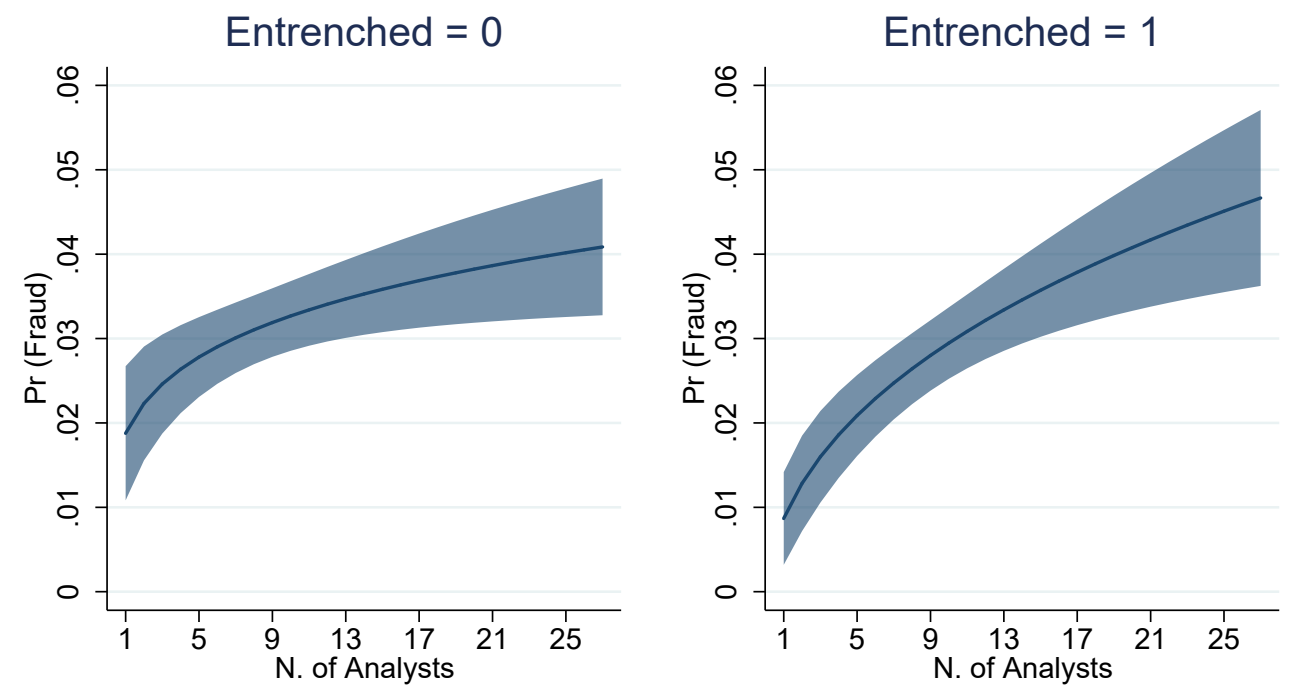

\section{Before 2007}
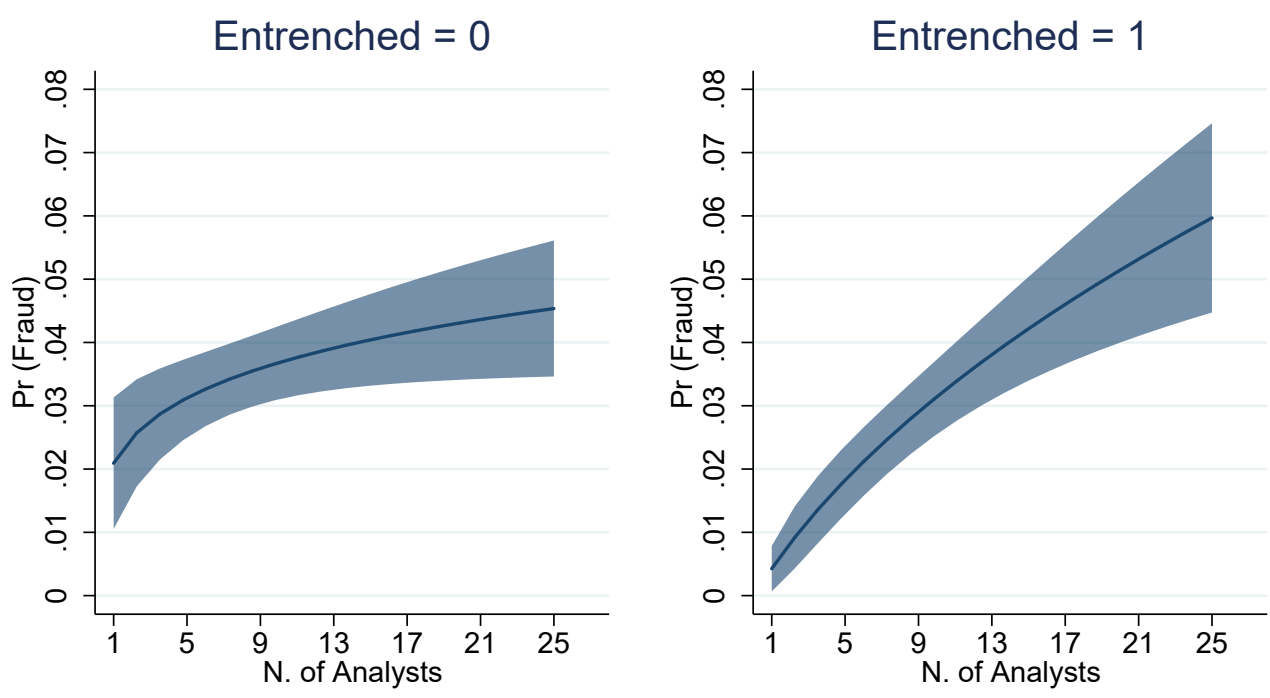


\section{Figure 4: Institutional Ownership}

The figure shows the estimated litigation risk (probability of being involved in a litigation event) for levels of (log-) coverage ranging from the 5th to the 95th percentile. Estimations are based on the coefficients of models (3) and (6) in Table VII and are reported separately for firms with high and low levels of managerial entrenchment. High managerial entrenchment is defined as share of institutional ownership (or number of institutions with holdings larger than $2 \%$ ) below the median value. For ease of interpretation graph is rescaled on number of analysts (rather than the logarithm). The plot also reports the $95 \%$ confidence intervals for the marginal effects.

\section{Institutional Ownership}
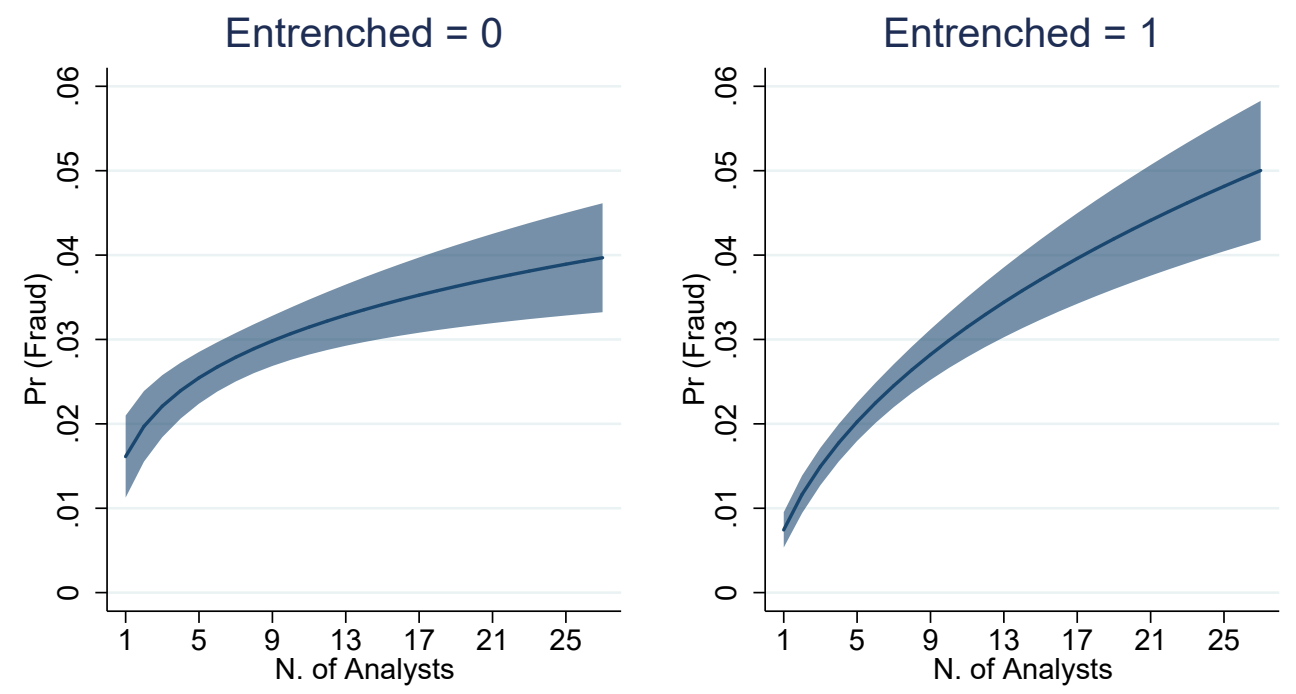

N. of Inst. Investors with holding $>2 \%$
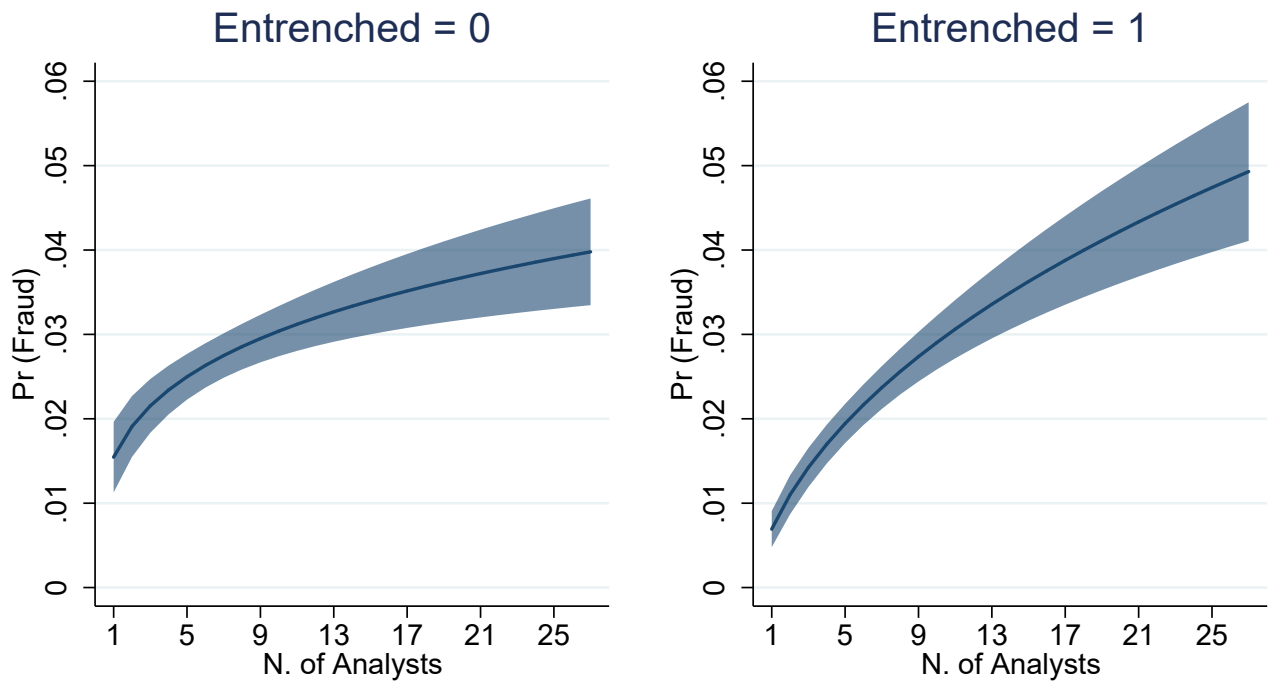


\section{Appendix A. Estimation of discretionary accruals}

Following Yu (2008) we use a modified version of the Jones model (Dechow, Sloan, and Sweeney, 1995), which estimates discretionary accruals from regressions of total accruals on changes in sales and on property, plant, and equipment within industries. Todetermine discretionary accruals, we run the following cross-sectional OLS regression by the first two-digit of the standard industrial classification (SIC) code to estimate coefficients.

$$
\frac{T A_{i, t}}{A_{i, t-1}}=\beta_{1} \frac{1}{A_{i, t-1}}+\beta_{2} \frac{\Delta R E V_{i, t}}{A_{i, t-1}}+\beta_{3} \frac{P P E_{i, t}}{A_{i, t-1}}+\varepsilon_{i, t}
$$

where $i$ indexes firms, $t$ indexes time, $T A_{i, t}$ is total accruals defined as Net Income (Compustat item NI) minus Cash Flow from Operations (item OANCF), $\triangle R E V_{i, t}$ is the change in sales revenues (item SALE), and $P P E_{i, t}$ is gross property, plant, and equipment (item PPEGT). All the variables used here are scaled by total assets at the beginning of the period (item AT). We estimate the cross sectional models separately for each combination of calendar year and two-digit SIC code with a minimum of 15 observations. We then use the estimated coefficients $\hat{\beta}_{1}, \hat{\beta}_{2}$ and $\hat{\beta}_{3}$ to define non-discretionary accruals as

$$
N D A_{i, t-1} \equiv \hat{\beta}_{1} \frac{1}{A_{i, t-1}}+\hat{\beta}_{2}\left(\frac{\Delta R E V_{i, t}}{A_{i, t-1}}-\frac{\Delta A R_{i, t}}{A_{i, t-1}}\right)+\hat{\beta}_{3} \frac{P P E_{i, t}}{A_{i, t-1}}
$$

Where $\triangle A R_{i, t}$ is the change in receivables (item RECT). Finally we define discretionary accruals as

$$
D A_{i, t-1} \equiv \frac{T A_{i, t}}{A_{i, t-1}}-N D A_{i, t}
$$




\section{Appendix B. Real Earnings Manipulation}

We follow a similar approach to develop empirical measures for real activities manipulation. Following, among others, Roychowdhury (2006), Zang (2012) and Irani and Oesch (2016) we use industry- and year-specific cross-sectional regressions to estimate the expected values of cash flows, production costs and discretionary expenses and use the estimated coefficient to build firm-year specific measures of real earnings manipulation based on the "abnormal" values of these quantities.

\section{Abnormal Cash Flows}

We express normal CFO as a linear function of sales and change in sales. We estimate this model with the following cross-sectional regression for each industry and year combination:

$$
\frac{C F O_{i, t}}{A_{i, t-1}}=\beta_{1} \frac{1}{A_{i, t-1}}+\beta_{2} \frac{S A L E S_{i, t}}{A_{i, t-1}}+\beta_{3} \frac{\Delta S A L E S_{i, t}}{A_{i, t-1}}+\varepsilon_{i, t}
$$

For each firm-year abnormal cash flow is defined as the actual level of actual cash flows minus the expected level of cash flows calculated using the estimated coefficients from this model. $C F O_{i, t}$ is cash flow from operations in period (item OANCF minus item XIDOC).

\section{Abnormal Production Costs}

Again we first estimate the expected level of production costs for firms in certain year and industry with the following OLS model:

$$
\frac{P R O D_{i, t}}{A_{i, t-1}}=\beta_{1} \frac{1}{A_{i, t-1}}+\beta_{2} \frac{S A L E S_{i, t}}{A_{i, t-1}}+\beta_{3} \frac{\Delta S A L E S_{i, t}}{A_{i, t-1}}+\beta_{4} \frac{\Delta S A L E S_{i, t-1}}{A_{i, t-1}}+\varepsilon_{i, t}
$$


Where $P R O D_{i, t}$ is production costs defined as the sum of Cost of Goods Sold (item COGS) and the change in inventories (item INVT). The abnormal production costs for each firm-year are computed as the difference between the actual values and the expected levels predicted from this equation.

\section{Abnormal Discretionary Expenses}

Wemodel discretionary expenses as a function of lagged sales and estimate the following model to derive normal levels of discretionary expenses or firms in each industry-year:

$$
\frac{D I S X_{i, t}}{A_{i, t-1}}=\beta_{1} \frac{1}{A_{i, t-1}}+\beta_{2} \frac{S A L E S_{i, t}}{A_{i, t-1}}+\varepsilon_{i, t}
$$

Where $D I S X_{i, t}$ represents the discretionary expenditures defined as the sum of advertising expenses (item XAD), R\&D expenses (item XRD), and Selling, General and Administrative Expenses (item XSGA). Abnormal discretionary expenses are computed as the difference between the actual values and the expected levels predicted from this equation. 